\title{
Political Cartoon at the Service of West Belarus Left Wing Movement: the Journal 'Malanka'
}

\author{
BY
}

ANASTASIJA ASTAPAVA*

The Polish-Belarusian ethnic humour has been employing recurrent stereotypes for centuries. In Belarusian jokes, a Belarusian lower-class trickster often fools the Polish noble - pan, yet, ridicules oneself too. In the following joke, a Belarusian pauper begs alms from the pan:

Dear pan, please, donate to the blind!

What kind of blind are you if you are reading a newspaper!

$\mathrm{Oh}$, what kind of reading is it, I am just looking through the pictures!

(Malanka 1928(4): 3)

This example, from the West Belarusian newspaper Malanka ('Lightning', 1926-28) provides the typical illustration of a trickster joke. In spite of their similarities, such pieces of humour sometimes pursue certain objectives, not serving just as jokes for the sake of joking. The humour may become instrumental for the mediation of different ideologies, as it happened after the 1921 Polish-Soviet war, when the Belarusian territory was divided between Poland and Soviet Union. The border suddenly split the strains of Belarusian intellectuals who had been so close to the country's independence in 1918 (when Belarusian People's Republic formed). The West Belarusians intellectuals on the Polish side employed humour in their press not only to cope with the new realities, but also sometimes to translate their pro-Soviet leftist moods to the target audience - the Belarusian peasants and workers.

The West Belarus mass media tremendously multiplied in the 1920s largely due to Polish democratization. As a result, freedom of expression gave way to a variety of opinions in the public sphere. Paradoxically, the Eastern side Soviet korenizatsiya and the emergence of humorous press (and communist cartoons in particular) simultaneously inspired the West Belarusian media. This article

* Anastasija Astapava is a PhD student at the Department of the Estonian and Comparative Folklore, University of Tartu, Estonia. In December 2015, she is defending her dissertation 'Negotiating Belarusianness: political folklore betwixt and between'. In the dissertation, she researches vernacular creativity emerging as a response to negotiating Belarusian political and ethnic identity: jokes, surveillance and Potemkin village rumors, folk biography of Lukašenka, and nationalist narratives among major topics. The author wishes to thank Uladzimir Arloŭ, Dagnasław Demski, and Liudmila Nalivajka for their help in my search for and analysis of the cartoons. This research was supported by Institutional Research Project 'Tradition, Creativity, and Society: Minorities and Alternative Discourses' (IUT2-43). 
suggests looking at the multiple scholarly contradictions upon the 1921 division of Belarus and the political situation in West Belarus through a case study - the exemplary sample of West Belarusian cartoons. Drawn in Malanka, the satirical publication of the leftist West Belarusian organisation Hramada, they combined the propaganda elements invigorated by the Soviet cartoons with the locally conditioned features, becoming a novel and applied genre. A tool for anti-state propaganda, Malanka and other leftist journals simultaneously became a product of relative democratization of West Belarus, which allowed for a multitude of opinions. This article argues that the pro-Soviet West Belarusian cartoons became a specific form of expression, inspired by the seeming success of the Soviet 'miracle', but possible due to the certain liberties available for some time in the Second Polish Republic.

The sources for the research include the issues of Malanka available in National Library of Belarus and cartoons kept in the Archives of the National Art Museum of the Republic of Belarus - some still hand-drawn and most probably never published. Since Polish censorship confiscated many issues of the journal, some cartoons turn up in the archives only. The cartoons from the published issues also count as they are rarely accessed by researchers - most of them were never reprinted again. So far, scholars have mostly analysed Malanka as an organ 'for the struggle against the bourgeois regime for the social and national rights of Belarusians [...] uncovering different machinations of the landowners and capitalists' through its satire (Kachanoŭski 1989, 3). This research attempts to analyse the particular piece of West Belarusian pro-Soviet press avoiding certain reasoning for the analysis Soviet scholars might have had.

The structure of the article first of all includes the overview of the historical context in which Malanka appeared, with the short overview of the preceding Belarusian press and the overall Belarusian 1920s mass media situation. Then it turns to the history of the Belarusian satirical press and cartoons in particular to give a way to the description of Malanka per se: its foundation, publishers, ideology. In this part, the main themes and conflicts of Malanka cartoons as well as the recurrent expressive methods become the main object of analysis. At the end, the article gives an overview of the obstacles due to which Malanka was closed and the whole situation of the Belarusian press dramatically changed in the late 1920s.

\section{Historical Context of 1920s West Belarus}

After several attempts to proclaim a Belarusian republic in the early 20th century, the Peace of Riga in 1921 dashed any hope for a united and sovereign Belarus. This treaty marking the end of the Polish-Soviet War was signed by Poland, Soviet Russia (also on behalf of Soviet Belarus) and Soviet Ukraine. Along with other agreements, 
it divided the territory of Belarus between the Soviet Union and Poland. The territory of West Belarus and West Ukraine became the eastern part of Poland, often referred to as Kresy Wschodnie ('eastern lands of Poland'). The partition ultimately thwarted any efforts undertaken for Belarusian sovereignty. Now divided, the strains of the intellectuals lost their integrity. Each group had to act, taking into account the differing directions of the countries that now had ownership of the Belarusian territory.

In the 1920s, the Soviets came up with the policy of korenizatsiya ('indigenization') - promoting languages and cultures of the minorities in order to strengthen Soviet power. Multiple Belarusian schools, libraries, university programs, and cultural institutions were developed. Between 1924-25, 28.4\% of primary schools were teaching in Belarusian. By 1930, this number rose to $93.8 \%$. Eventually, the press in Soviet Belarus was almost exclusively in Belarusian. Many contemporary scholars acknowledge this 'remarkable success of Byelarussization' (Martin 2001, 261), even arguing that the real nationalization of Belarusians began only under the Soviet rule despite the earlier rise of national awareness (Bekus 2010, 67).

Meanwhile, the politics in West Belarus in the 1920s remained less consistent. Even though Belarusian deputies tried several times to force the Belarusian question onto the agenda of the Polish government (Rudling 2015, 18), the Polish government was still unsure on how to treat the minorities. The varying reactions about the Polish occupation among Belarusian intellectuals further complicated the issue for Polish officials.

West Belarusian activists had to relate to the Byelorussian Soviet Socialist Republic (BSSR), whether they wanted it or not. This came to define them politically, due to the split into rival camps - pro-Soviet and anti-Soviet. While the former 'openly flirted with the idea of unification under Soviet leadership', the latter 'unsuccessfully sought to utilize the local chapters of the Roman-Catholic church as a vehicle to nationalize the population' (Rudling 2015, 6-7). The third direction was a pro-Lithuanian faction, which was especially visible straight after the Riga Treaty. Some Belarusian activists laid hopes on the reunification of Belarusian-Lithuanian state, which caused the emergence of several partisan groups, bringing together up to 10,000 people; their terrorist attacks aimed to shake the Polish state (Šybieka 2003, 257-262).

Personal choices on which direction to follow in similar situations of division were mostly studied for the late Soviet period (Yurchak 2006). Meanwhile, perhaps, the most comprehensive and universally applicable research on the topic was done by an economist, Albert Hirschmann. The title of his book Exit, Voice, and Loyalty presents three possible choices people make in the economic or political system they are not compliant with: they exit (or immigrate), voice their dissatisfaction, or remain loyal to what they do not like due to certain reasons (most often, safety) (Hirschman 1970). All three options were well represented in West 
Belarus. According to different calculations, between 1921-39 around 130,000 people emigrated from Kresy (Bryhadzin and others 2002, 402). The majority of peasants carried on their everyday activities and along with the loyalist Belarusian parties did not show many signs of dissent. The minority group this research will focus on, however, voiced their dissatisfaction. The contradictions and changes of exit, voice, and loyalty certainly emerged not only within the West Belarusian situation as a whole, but also as attitudes, that could exist within one person. The case of Branislaŭ Taraškievič, a peasant son, who studied in Saint Petersburg, Russia before World War I and became the author of the first Belarusian grammar book, exemplifies this notion. At the beginning, he hoped that Poland would help Belarusians, but, when it did not help, he changed his values and entered the Communist Party in 1926 (Tomaszewski 2014, 14).

The ideological constituents in the historians' accounts further perplex the analysis of this particular historical situation of West Belarus. For instance, Polish sources underlined its slow but steady development in 1920-30s, while Soviet historiography insisted on the strong oppression of Belarusian workers and peasants by the bourgeois Poles (Savchenko 2009, 97). Maźko states that the national movement in West Belarus belongs to one of the most complicated and neglected questions in the Belarusian (and Soviet) historiography (Maźko 2004). Even the Belarusian Peasants' and Workers' Union Hramada, which once included 100,000 members, has only one monograph written about it (Palujan 1976).

Hramada emerged under the influence the Communist Party of West Belarus in 1925, yet, pursuing distinct aims. The first point of its program, written by its head, Branislaŭ Taraškievič, voiced the demand to unite all the Belarusian lands into a single and sovereign republic governed by peasants and workers (Šybieka 2003, 268). The scholarship has mostly described Hramada as the strongest political party and the most powerful pro-Soviet organisation of West Belarus. Along with its large membership, Hramada established itself internationally by communicating with other European minorities, e.g. European Conference of Peoples in Geneva (Rudling 2015, 197). According to some researchers, the financial source of Hramada's strength remains unconfirmed (Vaškievič 2006, 47), whereas many argue that it was funded by Soviet money (Korienievskaia 2003; Rudling 2015, 207; Jackson 1966, 203; Šybieka 2003, 268). The funding, however, might have been inconsistent since the publishers of Hramada's periodicals often had to advertise subscription and asked its target audience - peasants - to pay for it, rather than disseminating the journals for free.

Hramada aimed to explain the laws and inform Belarusians of their legal rights e.g. providing templates on how to do a reclamation paper. It unequivocally demanded the redistribution of lands and the promotion of Belarusian language and culture. Especially successful in the latter direction, Hramada supported the 
Belarusian School Society to promote education in Belarusian. In 1925 only, they succeeded in establishing more than 400 Belarusian schools (Palujan and Palujan $1962,83)$ in addition to a number of libraries. Even though the organisation addressed the literate Belarusians in their press, as the Malanka case will further show, the messages were meant to be simple and comprehensive.

Hramada was not the only representative of Belarusian nationalist movements. The range of Belarusian political parties along with the relevant tolerance towards their radicalism of Polish officials allowed the Belarusian intelligentsia a chance to work within the growing democracy giving voices to a variety of speakers. The growing amount of the Belarusian press, the platform for the expression of the variety of opinions within a great number of genres, became the essential aspect of this development.

The press contesting authority had been at service of the Belarusian nationalism for a while. The first legal newspaper published in the Belarusian language, Naša Dolia (1906), a radical political weekly intended for 'rural and local working people', had only six issues published with four of them confiscated. The court officially closed the newspaper in 1907 also sentencing its editor to one year of prison. Parallel to the publication of Naša Dolia, the leaders of Belarusian Socialist Hramada found Naša Niva in 1906 in Viĺnia (Konan 1999, 313-314).

Naša Niva promoted both social and national liberation of Belarus and became a legendary newspaper nationalists would extol even today. 'Do not think that we wish to serve only the gentry, or the peasants. No, never! We want to be servants of the whole long-suffering Belarusian nation', the publishers declared (Zaprudnik 1993, 64). The incompatibility between the appeal to the times when Belarusians had their own nobility and the ideas of the liberation of the common people led to the formation of the predominant leitmotifs of Naša Niva - hard life on the Belarusian native land, injustice, and social inequality (Bekus 2010, 60). The newspaper published the news about Belarus and works of literature by Belarusian amateur and professional authors. Major Belarusian writers - Alaiza Paškievič, Janka Kupala, Jakub Kolas, Zmitrok Biadulia, etc. - came from the circle of Naša Niva. Officials closed Naša Niva in 1915, but it was revived again in 1920 (9 issues published) and 1991 (Dubaviec 1999; Lis 1999; Konan 1999b).

In the 1920s, the West Belarus press was oriented by the tradition laid by Naša Niva. A number of newspapers and journals were published simultaneously by different political parties and groups of intellectuals. These groups leveraged their new-found outlets through various means, for example: raising political questions, publishing letters and information about resistance from different countries, offering news from the USSR, works of literature, reviews of theatre performances and books, folk poetry, etc. As West Belarusian political parties, West Belarusian news- 
papers had a variety of ideologies behind them, not necessarily purely pro-Polish, pro-Soviet, or pro-Lithuanian. An example of these would be Pravaslaŭny Bielarus and Pravaslaunnaja Bielaruś insisting on the rights of Belarusians to use their own language in church. Founded in 1921, the Belarusian student union also published a variety of journals of different ideologies (Novy Šliach, Studenckaja Dumka, Volnaja Dumka, Novaja Varta, etc.), all related to student life (Paharely 2014b, 132).

The administration, ultimately, had final approval allowing newspapers to be established. After 1926, the number of rejected applications increased (Korienievskaia 2003). Yet the Polish policies towards minorities and their nationalist developments often operated on the preventive level; in 1925-26 they confiscated roughly $20 \%$ of the Belarusian press (Kovkiel' and Iarmusik 2002, 478) causing the closure of many newspapers. Often, the editorials of the newspapers did not even try to reopen the closed publications and immediately started new ones. This explains the plenitude of journal titles the Belarusian press used in the 1920s uncovering the contradiction between the revival and the suppression.

Hramada had many publications within its history. Published since 1926, using the Latin alphabet, Narodny Zvon (7 issues appeared) aimed at the Belarusian catholic audience who were less familiar with Cyrillic. Žyćcio Bielarusa $(1925,20$ issues published) had a special rubric about the state-building and cultural life in the Belarusian Soviet Socialist Republic (BSSR). After it was closed, the tradition was continued by Bielaruskaja Niva publishing the news from the BSSR and reviews on theatre and art works of Soviet Belarus. The newspapers of Hramada, Žyccio Bielarusa, Bielaruskaja Niva, Bielaruskaja Sprava were published weekly with a circulation of 2-3 thousand copies; Narodnaja Sprava and Naša Sprava were published biweekly with 5 thousand copies (Korienievskaia 2003).

Pro-Soviet leftist newspapers seem to have been considered more threatening and radical by the Polish government. While Hramada was the most influential party in West Belarus, its journal Avadzień ceased to exist with the tenth issue; Malanka - with the forty third. The comparison to 633 issues of Bielaruskaja Krynica (of Belarusian Christian Democratic movement) published tells a lot about the distribution of suppression and fears of the Polish government. The number of titles published by the Communist party of West Belarus within 17 years of its existence - Čyrvony Sciah, Baíšavik, Kujmy Broń, Partrabotnik, Vestki z SSSR, Barykada, Baraćba, Bielaruskaja Hazeta, Žyćcio, Asva, confirms how short-live they were. The following list illustrates how brief the lifespan of a newspaper published by Hramada was:

Žyćcio Bielarusa 19.8.1925-12.11.1925

Malanka 15.1.1926-26.12.1928

Narodnaja Sprava 19.6.1926-27.11.1926

Naša Volia 4.3.1927-12.3.1927 
Naš Holas 27.1.1927-28.2.1927

Naša Sprava 30.11.1926-22.1.1927

Narodny Zvon 7.12.1926-30.3.1927

The West Belarusian press had a possibility to thrive in 1920s - mostly before Józef Piłsudski's Coup d'État (1926) and the following persecution of the Belarusian nationalist leaders, those of Hramada (1927), in particular.

\section{From The Communist to Malanka: Satirical Journals and Cartoons in West Belarus}

Humour has always been an effective tactic to create solidarity by helping to get the message across, focusing on salient points, and attracting attention to adverse conditions; it was always helpful for bringing the message to less literate groups. Radical cartoonists helped in drawing hundreds of thousands of Americans into a mass socialist movement that grew to become the single greatest challenge to the domination of corporate capitalism in United States' history. Simple, politically pointed, and cheaply reproduced black line cartoons gave the movements a kind of visual exuberance and common set of anti-capitalist values (Cohen 2008, 36). Through their ironic, angry, and energetic cartoons, popular radical movements found a class politics of laughter which could illustrate the common values of the movement (Cohen 2008, 58). Cartoons often become the important mediator of propaganda, used as a means of persuasion and 'spreading its claims and the principles upon which it makes its claim' (Morgan 2005, 69). As history shows, this propaganda served especially well in the communists' hands.

One of the most famous platforms for the socialist political cartoons became The Communist (1920-1923), the weekly official organ of the British Young Communist Party, followed by Worker's Weekly. The most famous Soviet journal of political cartoons was Krokodil. Published since 1922, this all-Soviet journal was accompanied by local satirical journals targeting capitalist values and supporting communist future. For instance, among other topics, the Tatar Čajan laughed at the former rich - mullahs, affluent peasants and beys, while the 1922 Ukrainian journal Chervonyj Perets' targeted the White anti-communist movement. The title of Uzbek journal Muštum, published since 1923, even translates as 'kulak' - the rich farmer who, due to his richness was a class enemy of the Soviet peasant (according to the Soviet doctrine). The most successful pro-Soviet cartoonist of that time was perhaps, Boris Efimov. His success resulted from the fact that he drew what he was expected to draw in the Soviet political cartoon. In the introduction to the collection of Efimov's cartoons, the Comintern Secretary Felix Kon wrote:

in the cartoons of comrade Efimov, the fuss of the imperialist predators becomes visible [...]. Skillful wielding his weapon a pencil, comrade Efimov shoots straight to his enemy with [...] the 
mockery, appealing at the same time to the workers of the USSR and the whole world for vigilance and rebuff (Kon 1931a).

Kon's introduction to Efimov's album provides a useful framework for defining a Soviet political cartoonist as 'the sentry armed with a pencil and sharp-sightedly observing the class enemy preparing new intervention and exposing its reception' (Kon 1931b, 3).

The professional political caricature involving bitter satire appeared in Russia only in 1905, but since then it became extremely popular (Moskin 2000, 70); unlike the Western elite approach to caricature, in Russia and the Soviet Union it was used as a special communication tool by the authorities to influence the broader public. Its rage and simplicity resonated with any reader or viewer (Dmitriev 1998, 96). As Alexander Golubev argues, the Central Committee and even Joseph Stalin personally sometimes handed down the themes for the Soviet Pravda caricatures 'from above' (Golubev 2010, 215).

Little wonder then that 'representation, often very expressive, and thanks to this able to evoke a particular effect' in political cartoon frequently replaces the reality (Demski and Baraniecka-Olszewska 2010, 16). The caricatures often become the hot situational commentary, having the ability to preserve the phenomena 'more difficult to grasp and preserve in other sources: spontaneous expressions of feelings, short-term emotions, temporary moods - the atmosphere of the period'. Caricatures undoubtedly become a tale of the culture of particular age, providing a modern reader with a source of information on the past conventions and ideas that have moulded the reality into culturally marked images (Demski 2013, 82). The way of perceiving the reality, present in the press, is the product of its period circulated among its target audience (Demski 2013, 83). At the same time, the cartoons prove permanence and deep-rootedness of certain images and stereotypes (Buchowski 2010, 305). According to Uhlíková, 'visualizations provide the most easily accessible representation of other cultures, with the result that mental images formed on the basis of seen images generate very stable stereotypes' (Uhlíková 2005, 13). The forming Belarusian self-perception could not exist without comparison to its eternal neighbours, who were now in power. As Demski and Baraniecka-Olszewska rightfully claim, it is impossible to discuss the issue of ethnicity without reference to existing power relation of that time as cartoons and jokes often aim at the stupidity of those other who are imagined as the unrighteous holders of power (Demski and Baraniecka-Olszewska 2010, 14). Moreover, the needs of time influenced the transformation of the stereotypes about Poles as others.

Undoubtedly, West Belarus cartoons published by pro-Soviet newspapers and journals, were largely inspired by the Soviet graphic satire. In 1927, Aleksanteri Ahola-Valo founded the Soviet Belarusian artistic union Pramien (1927-30) which included many artists of the humorous genre: Paviel Hutkoŭski, Jan 
Razanaŭ, Hienadź Zmudzinski, ect. They actively contributed to newspapers like Zviazda, Bielaruskaja Vioska, Bielaruski Pijaner, Rabočy, Čyrvonaja Bielaruś, and journals such as Maladniak, Malady Araty, Trybuna Mastactva, etc. on the topic of capitalism, bureaucracy, West Belarus, etc. They also mastered cartoons on everyday topics and friendly jests (Nalivajka and Šunejka 2011a, 18). The cartoons in Soviet Belarus experienced their Golden Age in a variety of topics and styles (Nalivajka and Shunejka 2011b, 18). Political cartoons developed along with other visual art propaganda forms, for example, agitplakat. Whether depicted in The Communist, Pramien art, or Malanka, the markers of various groups in their relation towards communist ideas were recognizable and repetitive: a Capitalist wore a cylinder, justice was blind, and a worker was poor.

The 1924 journal Avadzień ('Gadfly') eventually preceded Malanka. Both journals, are among the first satirical periodicals, which targeted mainly Polish officialdom. Avadzień was published biweekly in Viĺnia and addressed some of the problems of the time, including taxes and national suppression. Although the journal focused on crucial issues it did not become an important political organ. In addition to social issues, its founder and editor Anton Vasileǔski published satirical articles and humorous drama pieces. Most of the other authors of the journal hid themselves with pseudonyms as well as abbreviations. With its tenth issue in 1925, Avadzień ceased to exist, although it made occasional but not very successful returns in 1929 and 1933. Some of its authors including Janka Marazovič and Jazep Horyd later became the cartoonists of Malanka, the journal this article will concentrate on.

\section{Malanka: Publishers, Ideology, and the Main Themes}

As Demski and Baraniecka-Olszewska suggest, caricatures often fall outside the dispassionate analysis, even from a distant time, forcing scholars 'to defend or to present their world-view, their interpretation of the history of their nation - that is, to respond to those stereotypes' (Demski and Baraniecka-Olszewska 2010, 15). In spite of its careful analysis and lots of valuable data, the existing research on Malanka could not avoid Soviet ideology, depicting it as the oppressed organ of the liberation movement supported by the benevolent Soviet Union (Lis 1981; 1994).

Malanka appeared biweekly in Viĺnia from January 1926 to December 1928. The list of its authors was not permanent and sometimes remained clandestine, but Arsien Lis thinks that while Malanka had M. Lucevič as a cover editor's name, in fact, Janka Marazovič (under the pseudonym Janka Malanka) edited the journal (Lis 1994, 10). Malanka became a joint effort of several other authors: Mihaś Vasiliok, Halíaš Leǔčyk, Janka Pačopka, etc.; Janka Malanka, Jazep Horyd, Jazep Drazdovič, Mikalaj Vasilieŭski, etc. made illustrations for it (Kachanoŭski 


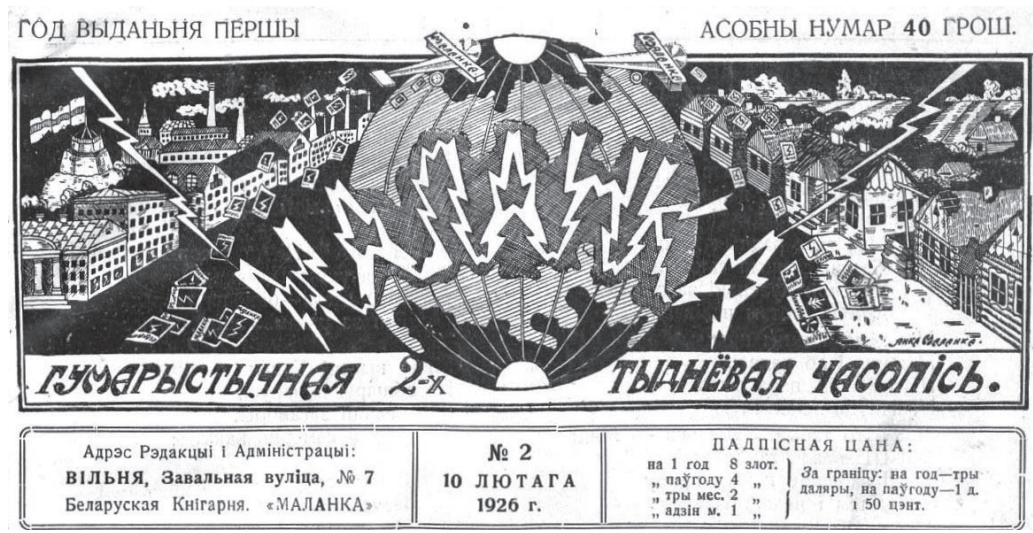

FIGURE 1: 'The title page of Malanka', by Ja. Malanka (Malanka 1926 (2): 1)

1989, 4). Jazep Horyd and Janka Malanka were major cartoonists, while Mikalaj Vasilieŭski replaced Horyd when the latter left for academic pursuits (Lis 1981, 95). The editorial staff included mainly young Belarusian poets, folklorists, linguists, translators, artists etc. Inspired by Hramada, they were interested in their own culture and promoting its values. Most of them used pseudonyms and grew into well-known cultural figures. Among the most famous, Janka Pačopka published in Naša Niva, West Belarusian children's journals, collected and published Belarusian folklore; Haĺjaš Leǔčyk collected folklore and ceramics patterns, composed poetry, translated many works of literature to Belarusian; Ivan Marazovič was the editor and cartoonist of several Belarusian periodicals issued in Vilinia; Jazep Horyd was the illustrator of many periodicals and books, author of graphites; Jazep Drazdovič was one of the most famous Belarusian artists, an archaeologist, writer, folklorist, architect, etc. As a whole, these authors published 43 issues of Malanka.

Polish officials confiscated many issues of Malanka (e.g. №3, 5) - and the authors replaced them by hurriedly published single issues of Piakučaja Malanka, Novaja Malanka, etc. Malanka often addressed the readers asking them to subscribe to the journal and pay for a subscription. Such a request challenges the argument that the Communist Party and its branches had consistent (Soviet) funding.

A typical issue of Malanka consisted of cartoons as well as jokes, poems, and other humorous forms. It also included correspondence with the readers e.g. letters from them and responses to these letters. Many of the published letters carried complaints about poverty and thankfulness to Malanka for defending poor Belarusians. Some letters, as the editors wrote in Malanka, came from abroad, in particular, the United States. The letters from abroad praised Malanka, while requesting new issues to be sent. Nowadays, it is unclear whether these letters were really written, and, if so, how much they were edited by Malanka. Also, the journal published the cartoons on international political themes as well as cartoons 


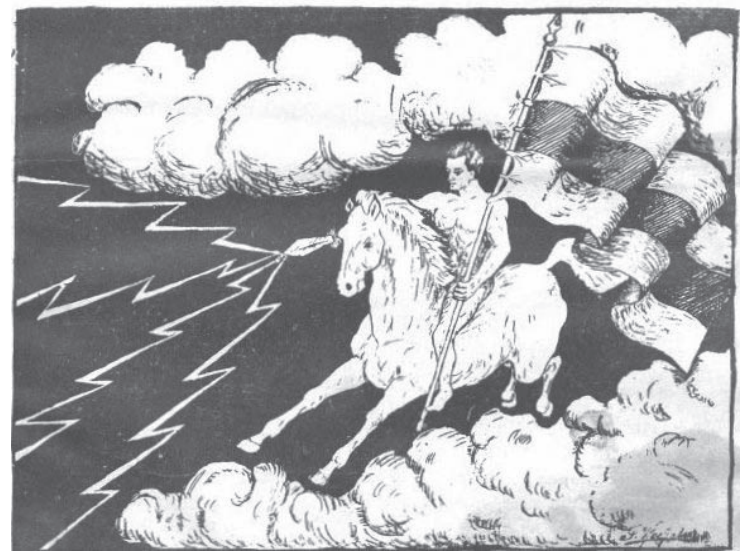

FIGURE 2: White-red-white flag, author unknown (Malanka 1926 (9): 1)

by the renowned Soviet cartoonists. Sometimes it addressed everyday life issues or universal topics of humour like drinking or stupidity.

Yet, Malanka primarily focused on politically themed jokes, poems, and cartoons. Like many other Belarusian nationalist newspapers, Malanka addressed Belarusian rural lower middle classes and literate peasants - the masses publishers wanted to imbue with the need of resistance. The publishers tried to reach the popular culture, the major everyday problems their addressees encountered, trying to explain what causes these problems on a higher level. Remaining sensitive to the problems and tastes of their audience, the authors simultaneously wanted to promote Belarusianization.

Malanka provided its vision of Belarusian history which corresponded to the visions laid by the first Belarusian newspapers, in particular, Naša Niva. The latter projected truly Belarusian statehood structures corresponding back to the high Middle Ages, in particular, the Grand Duchy of Lithuania, when Belarusian upper classes, great thinkers, princes and statesmen had existed; later defected en masse to Polish culture, leaving the Belarusian idea to peasants who had managed to preserve it for many centuries (Savchenko 2009, 66). Even though it was less possible for Malanka to carry these cultural myths through the humorous texts and cartoons, the allusions to ideas were always there.

For instance, Malanka included various cartoons that promoted its succession over Avadzień or mocked religion. Such topics would have been possible in many other pro-Soviet journals. Malanka, however, had very specific targets and recurring motifs which made it different from the Soviet press. For instance, the first issue includes 7 cartoons: 1- about Belarusian-Polish relationship, 2 about the connections to Avadzień, 1 - about the League of Nations, 1 - about Monarchism, 1 - about pany, 1 - about the Belarusian school reform. Despite some occasional side topics, certain themes appear again and again ranging from the first 
issue to the following ones. Pany in their relationship with Belarusians, particular local political parties and reforms, and capitalist, such as the League of Nations, became the most significant targets of Malanka humour.

\section{Poles, pany ('landlords'), and capitalists vs. Belarusian peasants and workers}

Analysing the major targets of the Soviet cartoon in Krokodil between 192239, Golubev claims that its major butts included (starting from the most popular ones): Germany, Great Britain, France, Japan, and the United States; Poland was only ranked sixth (Golubev 2010, 217) ${ }^{1}$. Undoubtedly, the distribution became different in Malanka, in which Poles occupied first place.

Generally, the worldwide cartoons mostly depicted a Pole as an arrogant military man or a beautiful young woman (Demski and Baraniecka-Olszewska 2010, 24). The depiction of a Pole in West Belarusian cartoons, however, diverged. Perhaps, unintentionally, Malanka carried on the implication of the earlier nationalist newspapers - of uniting the Belarusian national identity and social class into one. While Belarusian ethnicity was associated with peasantry (less frequently a worker), the Poles invariably stood out as capitalists. The latter in this dichotomy did not require any tools of presentation; the negative stereotypes Belarusians had about the Polish pany (landlords) transferred to the image of the bourgeois Poles. As Petrov writes, to make sure that the cartoon will hit its audience, 'the artist should be familiar with the audience's experience and stereotypes and be able to activate and provoke them' (Petrov 2010, 82).

Utilizing the stereotype of a Pole-pan rooted in the Belarusian thinking produced a widely employed strategy that was not only used in cartoons. Later research, for example, 'An outline of struggle of Belarusian people against Polish pany' (1940) published in eight chapters exemplified these tactics. According to its author, Iosif Lochmiel', the struggle against pany started in the Grand Duchy of Lithuania (Chapter I) and proceeded to the resistance of West Belarusian proletariat e.g. 'against Polish pany and capitalists' (Chapter VII). Chapter VIII is about the 'liberation of West Belarus and reunification of the Belarusian people' (Lochmiel' 1940). As Maźko fairly comments, this research attempted to extrapolate the conclusions about the 16-18th century relationship with Poles to characterize Polish attitudes towards Belarusians in West Belarus. As a result, Lochmiel' characterized Polish politics as a never-ending circle of economic, social, political, national, cultural violence, humiliation of Belarusians resulting accompanied by poverty (Maźko 2004). The example of Lochmiel's book illustrates the similarity of strategies pro-Soviet actors employed by bringing the common stereotypes and earlier historical events to characterize the new situation.

The images of Poles in Soviet cartoons were also researched e.g. in Nieviezhin 2006, Riabov 2006, Tokariev 2006, Lazari and Riabov 2008, Golubev 2010. 
The negative image of Polish neocolonialists embodied by the evil Polish pan / capitalist served as the means of bringing power relations to the surface and de-legitimizing authority (Teune 2008, 116). Malanka's humour served to make its audience permanently aware of the real nature of a Polish pan, always ready to harm a Belarusian. In1926, for instance, Malanka publishes a poem by Kandrat Krapiva, who was at the time living in the Soviet Union, expressed his position on Poland.

\title{
Крапіва. На «Крэсах Усходніх»
}

\author{
Пан клапоціцца на «крэсах», \\ Аб чыіх ён інтарэсах? - \\ Можна бачыць і сьляпому - \\ Не аб нашых-жа вядома, \\ Воўчы зуб не памагае, \\ Дык палітыка другая. \\ У яго, як бач, пасьпела - \\ Хвост пусьціць лісіны ў дзела; \\ Ходзіць, губкамі мыляе, \\ Констытуцыяй віляе, \\ Мажа губы, гладзіць вусы \\ Ён хахлу и беларусу: \\ «Мы вас любім, мы вам рады, \\ То чыноўнікі ўсе гады \\ Вас там крыўдзілі дагэтуль - \\ Мы пакажам ім за гэта... \\ Вось вам цацак (папяровых), \\ Вось вам школы, вось вам мовы... \\ Ходзіць пан лісой - хітрушкай \\ Перад крэсаваю птушкай. \\ Беларус, глядзі, не каркай, \\ Бо адчуеш сваім каркам, \\ Чаму пан таки стаў добры: \\ Кось-кось-кось пакуль у аглоблі, \\ Потым па баку дугою \\ Ды ў жывот яшчэ нагою. ${ }^{2}$
}

(Malanka 6 (1926): 6)

\footnotetext{
Krapiva. At 'East Kresy'

Pan is busy at 'kresy', / But with whose interests? / Even a blind can see - / Not with ours, / The wolf's tooth does not help, / So the politics is different. / He, as you see got ready -/ To involve the fox's tail into the business. / He walks pursing his lips, / Wagging with the constitution, / Smears lips, caresses moustaches / Of the Ukrainian and the Belarusian: / We love you, we are glad to have you, / The officials are skunks / They were harming you before - / We will revenge for that... / These are toys for you (from paper), / These are schools and the language... / Pan walks as a sly fox / In front of the bird from kresy. / Belarusian, watch out, do not croak, / As you will feel with your withers, / Why the pan became so kind-hearted: / 'Come-come' and drag you to the shaft, / And then beat your side with shaft-bow / And your stomach with the foot.
} 
Malanka also often depicts the misdeeds of the Polish pany, e.g. in the cartoon 'Contemporary bandits':

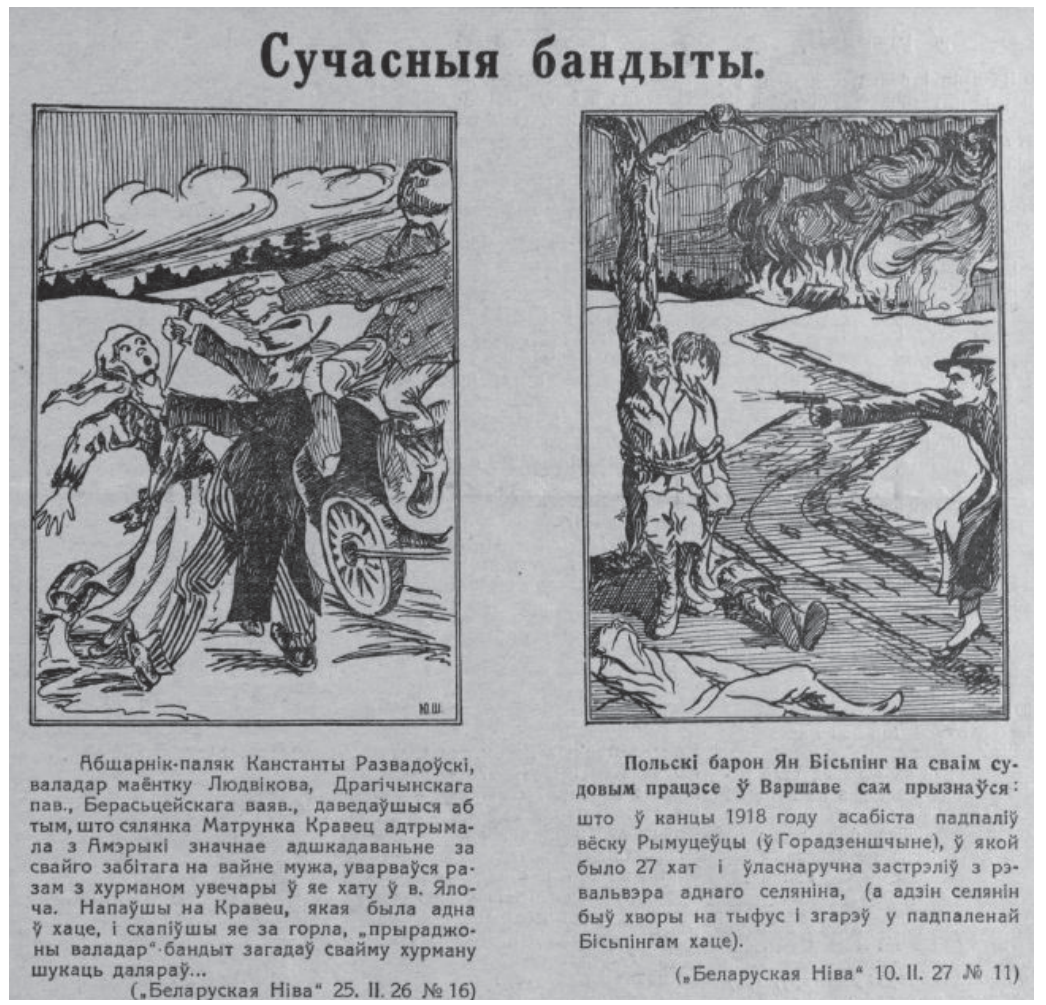

FIGURE 3: 'Contemporary bandits', author unknown (Malanka 1926 (6): 5)

To the left: Polish landlord Kanstanty Razvadoŭski, the owner of estate Liudvikava of Drahičynski paviet and Beraściejskaje vajavodstva, having learned that a peasant Matrunka Kraviec acquired a considerable donation from America for her husband killed at war, broke into her house in the village of Jaloča together with a wagoner. He attacked her when she was alone in the house, and, grabbing her by the throat, 'the inborn owner' - bandit ordered his wagoner to look for the dollars...

(Bielaruskaja Niva 25. II. 26 № 16)

To the right: Polish baron Jan Bisping confessing at his court session. At the end of 1918 he set the 27 house village of Rymuceŭcy (in Hrodna region) on fire and shot one villager with a revolver (and one villager was ill with typhus and burnt in the house Bisping set on fire).

(Bielaruskaja Niva 10.II.27 № 11)

In Malanka's dichotomy, Pole (pan, capitalist) - Belarusian (peasant, worker); the Belarusian is always the suffering one. Consider the following cartoon: 


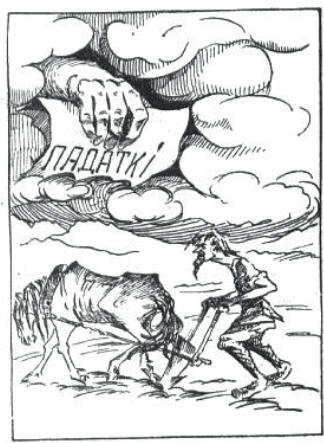

Селянін

Вясна. Пара ўжо селяніну ў плуг запрагчы сваю скаціну, Але-ж вось, як стогне ён, Пачаўшы 3 першых баразён

Калісь і сам быў дужы болей, Так цяжка ня было ніколі Конік некалі быў гладкі, Ды зьелі ўсё яму... падаткі

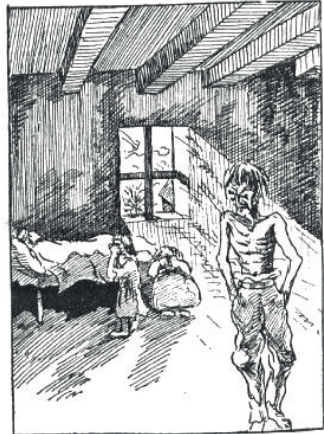

Работнік

Ані хлеба, ані солі,

Няма ў хаце яго болей.

Везработны - босы, голы,

Бяда, голад навакола.

Хвора жонка пролетара

Плача бедных дзетак пара,

Толькі сонейка адно

у яго глянула вакно.

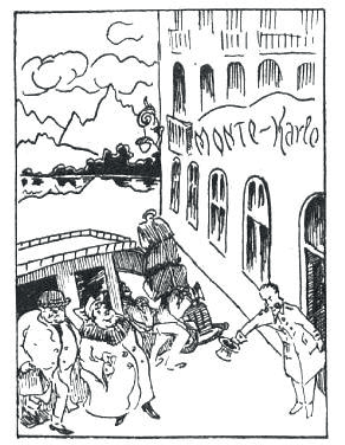

Пан

За граніцу 3 капіталам Паны едуць на вясну,

У "Монтэ-Карлё“ валяць валам Паражніць сваю машну.

Ўсё за грошы сабе купяць Рэчаносаў, лякаёў...

Хто-ж дарогу ік заступіць? Жыцьцё - рай для гультаёў.

FIGURE 4: ‘Peasant, worker, and pan', author unknown (Malanka 9 (1926): 4)

From left to right:

Peasant. It is spring. It is time for the peasant / To harness his animal, / But that is how he is moaning, / Starting with the first furrows. / Once he was much stronger, / It was not that hard ever / The horse was once sleek, / But the taxes ate him up.

Worker. There is neither bread, nor salt, / In his house. / Unemployed - barefoot, naked, / Misfortune and hunger are around. / The wife of the worker is sick / The pair of poor kids are crying, / Only the sun / Looks at his window.

Landlord (pan). With the money abroad / the landlords leave in spring, / They go to Monte-Carlo altogether / To empty their car. / They will buy everything for money: / The porters and doctors... Who will stop them? / Life is the paradise for the lazybones.

Glorification of workers and peasants, although less frequent than in the Soviet press, still had to appear in a journal that supported socialist values. The cartoonists depicted the workers and peasants mainly in their relation to pan. Also, the fact that more than $90 \%$ of Belarusians in West Belarus were farmers (Šybieka 2003, 276) justified the choice of a Belarusian peasant as one of the central figures.

\section{Poverty of the Belarusians}

Apart from the generally malevolent Poles, according to Malanka, unemployment and taxes were Belarusian peasants' and workers' main financial problems. In the anti-pany book quoted above (Lochmiel' 1940), Lochmiel' mentions about 
80 types of all-state and local taxes designed for the peasants in West Belarus, including the taxes for keeping cattle, crossing certain roads and bridges by the horse, melioration, bureaucratic work etc. For instance, a peasant had to pay at least two zlotys to gmina ${ }^{3}$ for stamping - proof of signature under his petition (Lochmiel' 1940, 122). Multiple fines and taxes took away about half of a peasant's budget. Since peasants often refused to pay them, their debt grew, and a special administrative division was created to extract the money from them (Lochmiel' 1940, 124). Lochmiel' may be exaggerating some facts due to the ideological direction of his research, but in many ways this still reflects the problems West Belarusians faced. Another author, Viačorka, describing the life of particular Belarusian settlement, Haradnaja, enumerates the taxes for keeping cattle and dogs, killing cattle, owning real estate and land (Viačorka 2014, 242). Introduced in 1923, kamasacyja, a measure of land consolidation aimed at eliminating cieraspalosica (when one's plots of land alternate with someone else's), laid all the costs on the peasants. The latter had to pay 14-20 zlotys for the projects of melioration, relocating the roads, etc. (Bryhadzin and others 2002, 401-402).

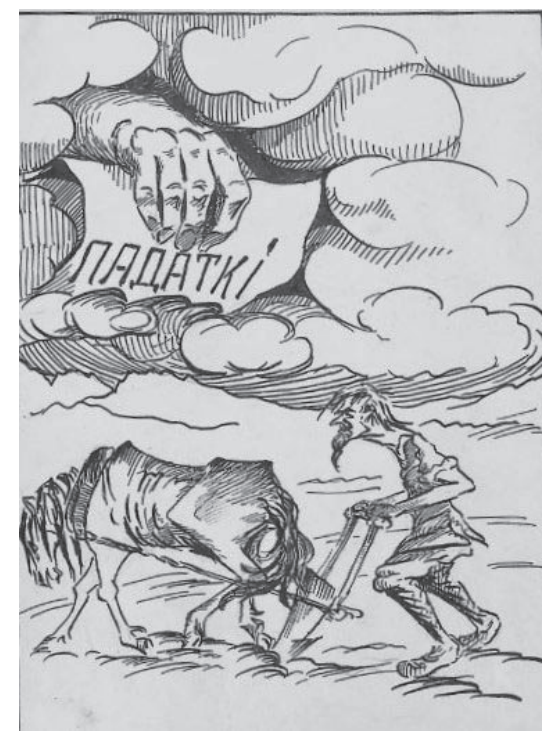

FIGURE 5: 'The hand demanding taxes from the peasant at plough', by Ja. Malanka (Archive). Reads: Taxes

The following cartoon from the Historical Archive, perhaps, never published, depicts the Belarusian peasant bitten by different dogs, with the 'taxes' one being the largest.

\footnotetext{
3 An administrative unit in Poland.
} 


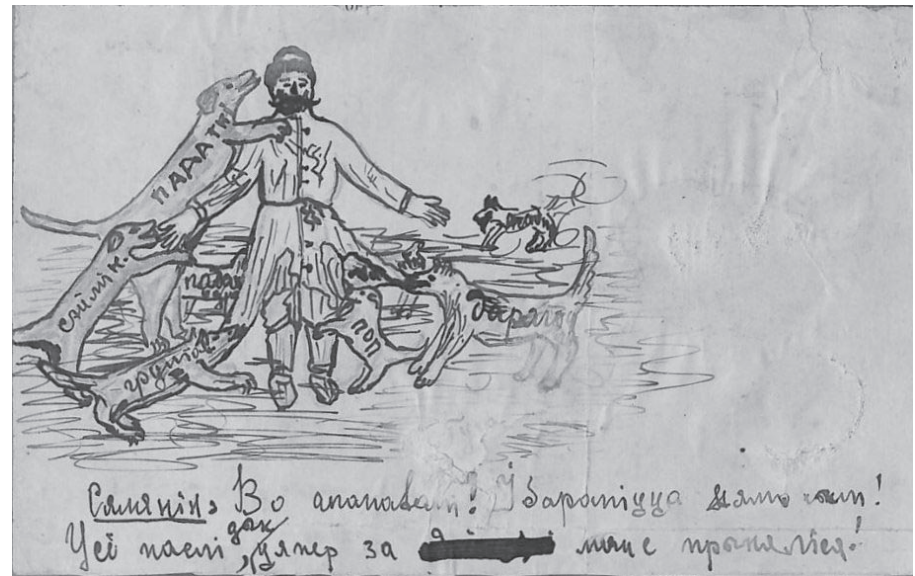

FIGURE 6: 'Peasant bitten by dogs', author unknown (Archive)

The motive of a peasant being torn from different sides is recurrent. In Figure 8 , multiple hands e.g. the pope, insurance, excise, duty, etc. stretch to the peasant on the first side demanding to give, but, when it comes to giving something in return to the peasant, in particular the school on the second side on the picture, he receives a fig.

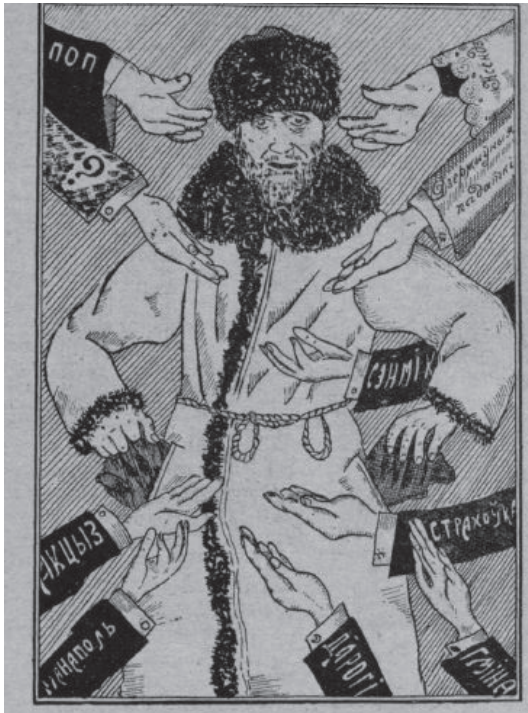

Дай! Дай! Дай!..

Беларус: Штодзень працягваюцца да мяне дзесяткі рук з дамаганьнем: дай! дай! дай!...
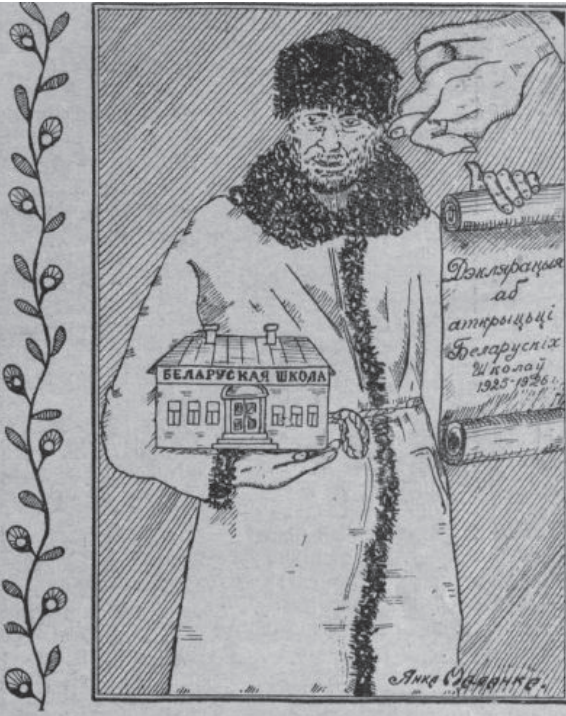

\section{Ha!..}

.. а як я выставіў дамаганьне сваей род най школы, мне далі єкветку» п. Міністра Асьветы Станіслава Грабскага.

FIGURE 7: ‘Give! Give! Give!’ by Ja. Malanka (Malanka 1926 (2): 5) 
Give! Give! Give!

Belarusian: 'Every day tens of hands are stretched to me with the demand: give! give! give!'

Take!

'... and when I tried to defend my native school I was given a "flower" from the minister of education Stanislaŭ Hrabski'.

In another, perhaps unpublished cartoon the demand to pay taxes appears from an oven before the holiday.

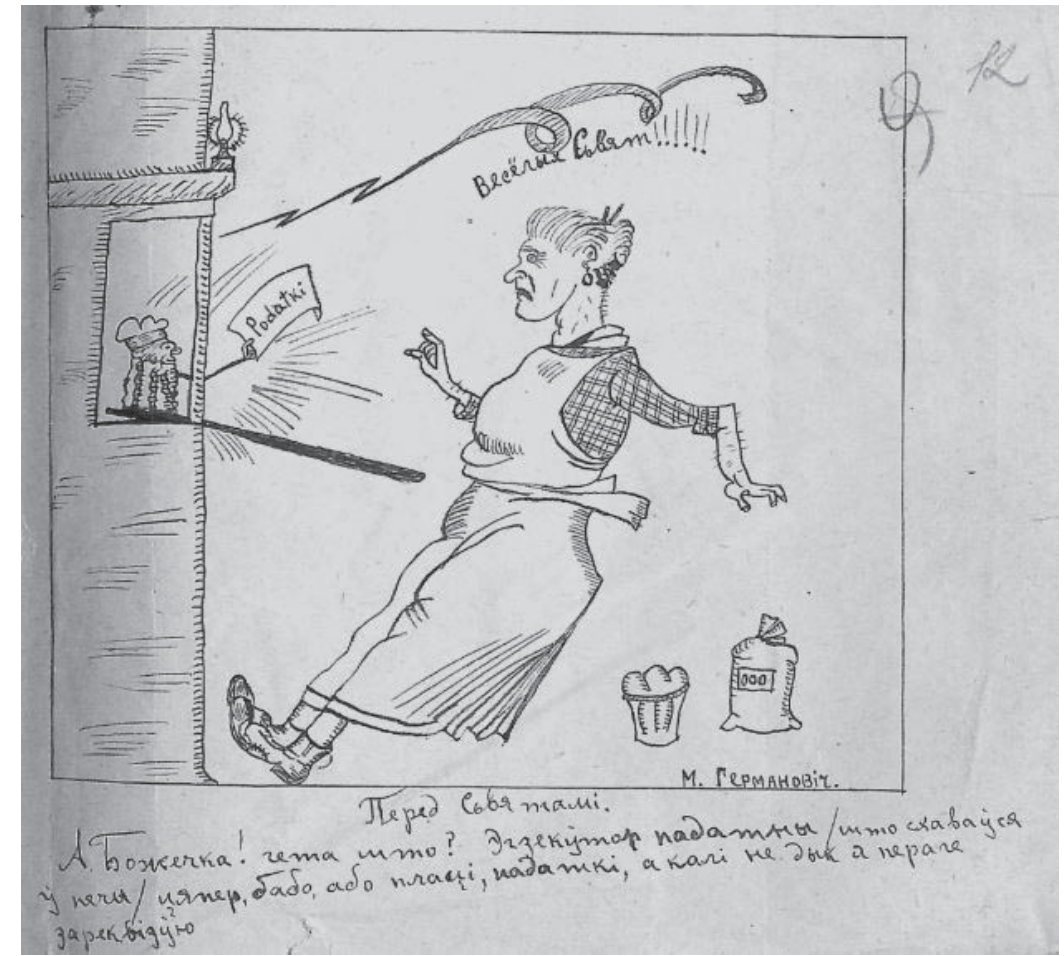

FIGURE 8: 'Before the holiday' by M. Hiermanovič (Archive)

Oh, god! What is this? The tax executor / hid in the oven / now, woman, either pay taxes or I requisition your cakes.

Yet, later, the first years of 1930 s statistics shows that $70 \%$ of the Belarusian peasants turned up below the poverty line, while only $23 \%$ received middle income (Kasciuk and others 1995, 219).

Meanwhile, West Belarusian workers suffered from unemployment. According to Kasciuk, in 1927, only $13.6 \%$ of unemployed workers received paltry social payments (Kasciuk and others 1995, 215). 
FIGURE 9: 'Destiny of the workers', author unknown (Malanka 1926 (4): 4)

The factories died away. The hungry working people are looking for jobs here in vain.

Underfed workers are looking for help in the state organisations, but the representative of the government says as usually: There is no help and there won't be.

Rest in peace, dear worker! Now you need neither job nor governmental help, even the eyes of the hungry wife and children will not wake you up...
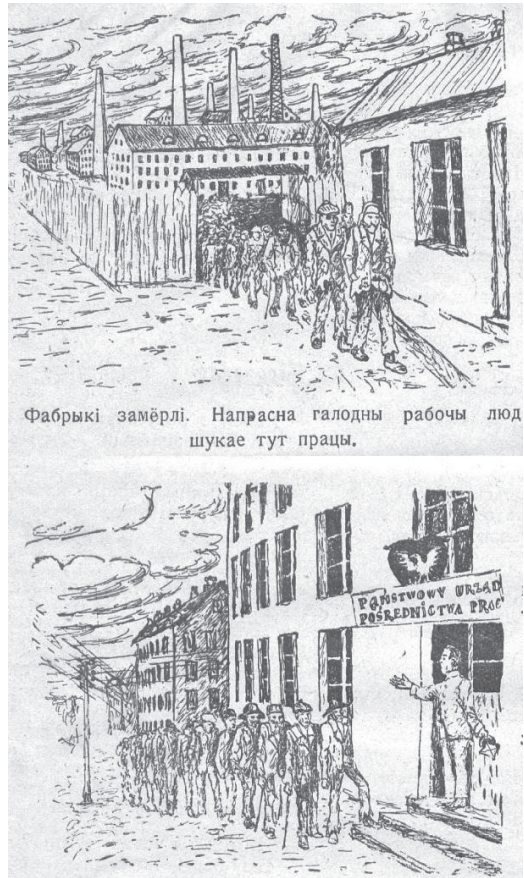

Змораныя голадам работнікі шукаюць помачы у дзяржаўных установах, але ўрадовец кажа: як заўсёды:

- Запамогі няма, ды й ня будзе!

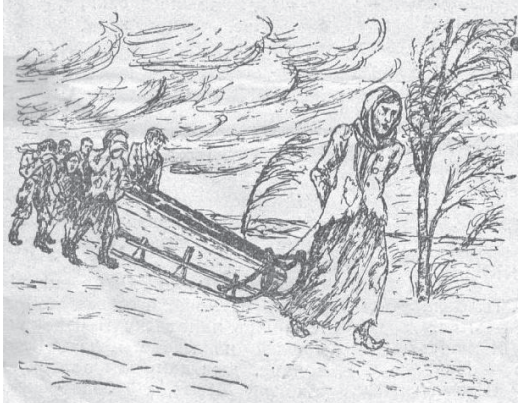

Ідзі на вечны спачын, дарагі работнік! Ня трэба табе уॅжо а ні працы, а ні ўрадовай запамогі, на ват енкі галодных жонкі і дзяцей не разбудзяць цябе...

\section{Struggle with Other Parties: Endeki, Manarchisty, the Actors of Agrarian Reform, and Doctor Paŭliukievič}

Struggling against the Polish suppression and for the well-being of Belarusians, Malanka, representative of the Hramada political movement, also had to show its attitude towards other political forces and parties. Clearly, the most hostile party as seen by Hramada was the leading party of Polish nationalists, Narodowa Demokrac$j a$, mostly referred to as Endecja and its representatives called Endeki. Narodowa Demokracja refused to acknowledge the minorities living in Poland as separate eth- 
nicities and sought to assimilate and 'civilize' them into Poles. As the leader of $\mathrm{Na}$ rodowa Demokracja, Roman Dmowski, once stated: 'Our aim is to become a strong nation, one nation that cannot be defeated. Where we can, we should civilize foreign elements and expand our potential by absorbing these elements into our nation. Not only do we have a right to do so, but this is our duty' (Dmowski 1904, 214-215).

Endek and pan become synonymous in Malanka which accuses them of neglectful attitude and harmfulness towards Belarusians. In the following cartoon, the front figure represents Endecja dancing with the Polish Socialist Party on the book of Agrarian reform strangling peasants. The representatives of both parties have pig snouts - the detail which one can notice only after carefully looking. Their dance is accompanied by the orchestra of Piast (Polskie Stronnictwo Ludowe 'Piast'), Wyzwolenie (Polskie Stronnictwo Ludowe 'Wyzwolenie') and most probably (the abbreviation is illegible) National Workers' Party (Narodowa Partia Robotnicza). Unlike the well-dressed Sejm members enjoying themselves, the peasants are naked and suffering.

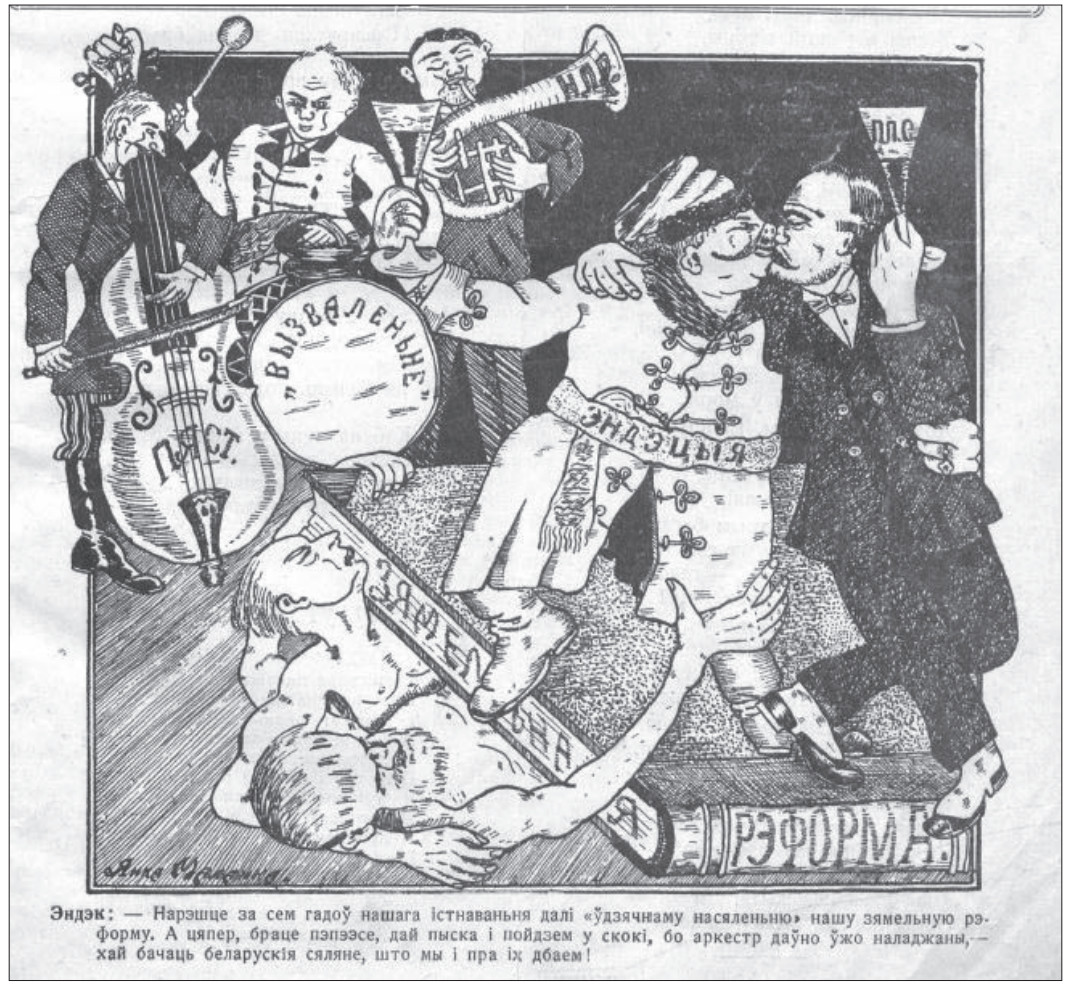

FIGURE 10: 'Dance of the parties', by Ja. Malanka (Malanka 1926 (2): 1)

Endek: finally, after seven years of our existence we gave our land reform to our 'thankful people'. And now, PPS [Polish Socialist Party] brothers, give your mug and let's dance as the orchestra has been arranged long time ago, - let the Belarusian peasants see that we look after them. 
The agrarian reform mentioned on the 'Dance of the parties' cartoon was the issue of multiple debates in the Polish Sejm. After the unsuccessful attempt to bring more Polish landowners to West Belarus, to stimulate the profit from farming by rekindling economic exchange and sales, Poland still had to stabilize West Belarusian agriculture (Gres' 2014a). Rural economy remained one of the major concerns in the Second Polish Republic, and mainly non-oppositionist parties, by definition hostile to Hramada, paid attention to its development. For instance, the program of Wyzwolenie suggested limiting the amount of private lands without paying any compensation to those who owned more than recommended. To attract Belarusians, the party also promised autonomy to West Belarusian lands. Similarly, Polska Partia Socjalistyczna (PPS) seemed to promote reforms (Gres'2014b). Malanka shows all the major parties flying as storks over the Belarusian peasant, peacefully ploughing the field.

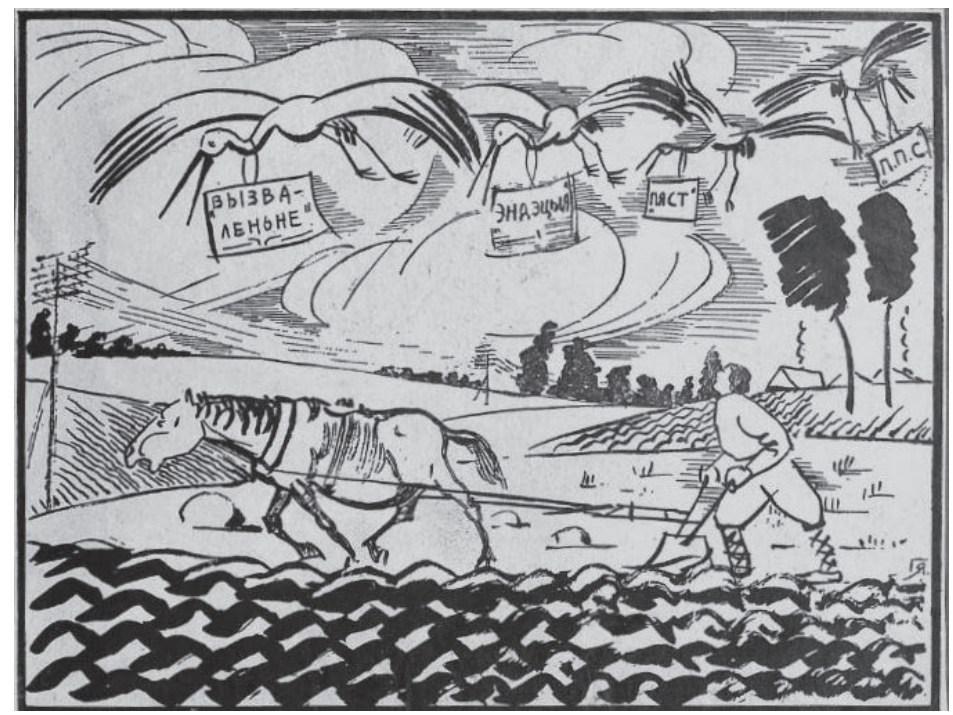

FIGURE 11: 'Party storks over the Belarusian peasant', by Jazep Horyd (Archive)

Another West Belarusian problem mentioned above concerned the Polonization measures actively implemented by both Władysław Grabski, the prime minister of Poland in 1920 and 1923-25, and his brother, Stanisław Grabski, a minister of religion and education from National Democrats in 1923 and 1925-26. Stanisław Grabski did not only state 'Polish land for the Poles!' (Blanke 1990, 89), but also became the author of the so-called Lex Grabski law (1924) on language and schools for the national minorities. The Lex Grabski law sought to eliminate Ukrainian and Belarusian languages from Polish schools. In Poland, primary school subjects and the core subjects of grades four to seven were taught in Polish. Science classes at schools with over $40 \%$ of non-Poles could be taught in Belarusian (Rudling 2015, 169). Only in the regions where Belarusians were at least $25 \%$ of the population, 


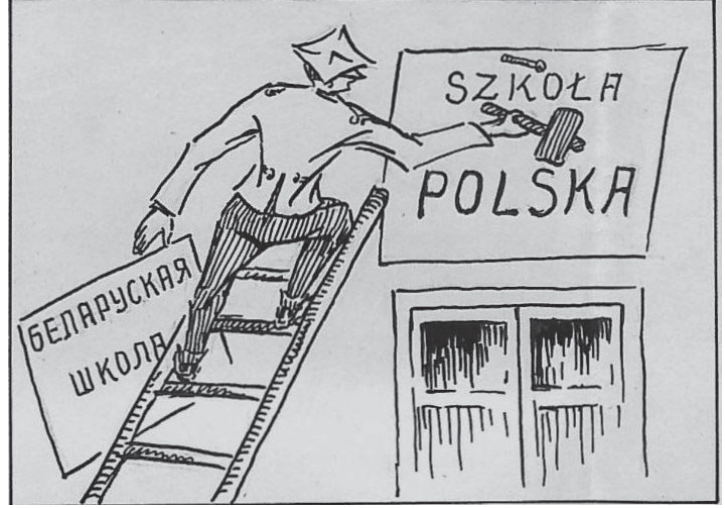

FIGURE 12: 'Change of Belarusian school into Polish', author unknown (Archive)

they could open a Belarusian school. In this case at least $40 \%$ of the school-aged children's parents had to express their wish for that. To open a school, one had to make an application with the signatures of notary and the head of the settlement to the school inspector. If there were 20 signatures, a double-language, Belarusian and Polish, school was opened (Ladysieŭ and Bryhadzin 2003, 165). The closure of the Belarusian schools and the negative image of Stanisław Grabski became one of the major themes of Malanka cartoons.

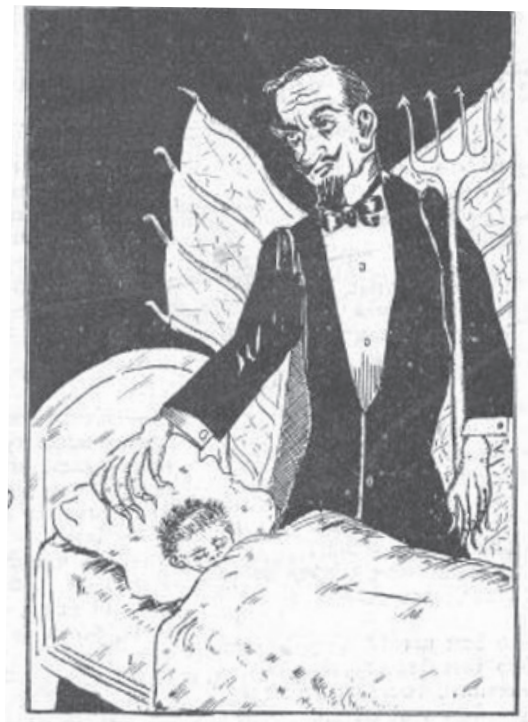

СІРАШНЫ СОН БЕЛАРУСКАГА ДЗІЦЯЦІ. Дзіця праз сон, убачыўшы цень міністра асьветы Станіслава Грабскага :

- Адчапіся ад мяне страшная мара. Ня вырвеш сваімі кіпцюрамі маей маладое душы. Я беларусам быў, беларусам ёсьць і беларусам буду, а твае языкоғыя ўставы і утраквістычныя (дауязычнья) школы зьнікнуць, як туман, разам 3 табою.
FIGURE 13: 'The nightmare of the Belarusian child', author unknown (Malanka 1926 (2): 4)

The child in the dream, after seeing the shadow of Minister of education Stanisław Grabski: 'Leave me alone, the nightmare! You will not tear out my young soul with your nails. I was Belarusian, I am Belarusian, and I will be Belarusian, and your language decrees and double-language schools will disappear as fog together with you'. 
FIGURE 14: 'Minister of Education Stanislaŭ Grabski', by Ju. Š. (Malanka 1926 (7): 8)

I. The reduction of schools and teachers; II. Extermination of the Belarusian schools.

Under the picture: The Minister of Education Stanislaŭ Grabski:

We should reduce the number of schools in half, and not open

Belarusian schools at all, as

why the peasant would need education if his business is to dig land and manure.

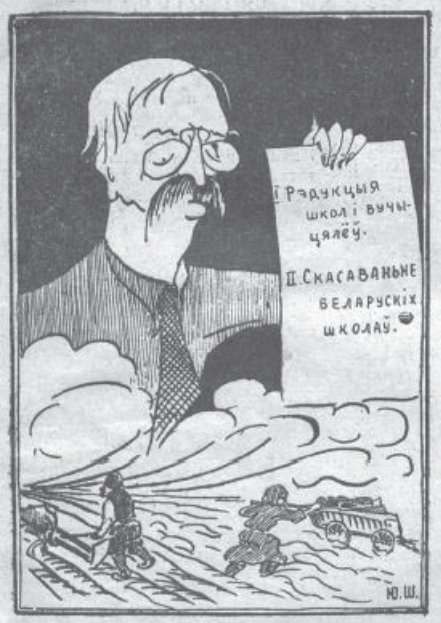

Mixicmap acobemb Cmaxicray̆ Jpaocki:

У імя ашчаднасьці трэба зьменшыць јік школаў амаль на палову, а беларусніх школаў сусім не адчыняць, 60 на што мужыку тая навука, калі яго справа, капацца ў зямлі i rнai...

The Monarchists became, perhaps, the next important focus of criticism in $\mathrm{Ma}$ lanka after Endeki, especially since the Monarchist Party had been founded in the Sejm. On the following cartoon a monarchist is appealing to God depicted as a tsar.

FIGURE 15: 'Monarchist (after the creation of the Monarchist party in the Sejm)', author unknown (Malanka 1926 (7): 8)

Monarchist: God! If you do not send father-redeemer, then better send death to me, since I cannot watch minorities living, growing, and gathering power, and workers obtaining their rights anymore.

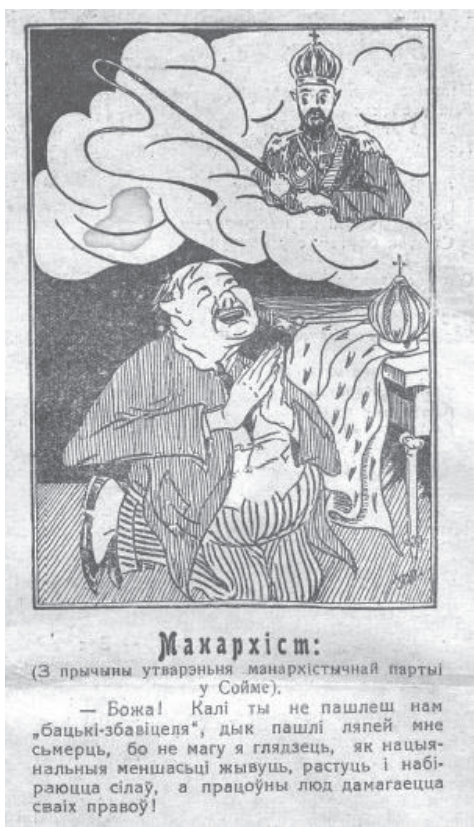


Malanka criticized the religiosity accompanying monarchism and mocked at the myth of father tsar, the redeemer, who will come to save his people (Chistov 2003, 474).

Similarly, on another cartoon, the monarchists walk on top of the peasants with their slogans, e.g. 'For the faith, for the tsar, for the motherland'. In the background, there is a huge figure of the monarch, keeping a bottle and a lash at his hand. The gallows next to him most probably carry the same function as what he keeps in hands, showing the negative sides of the monarchy regime.

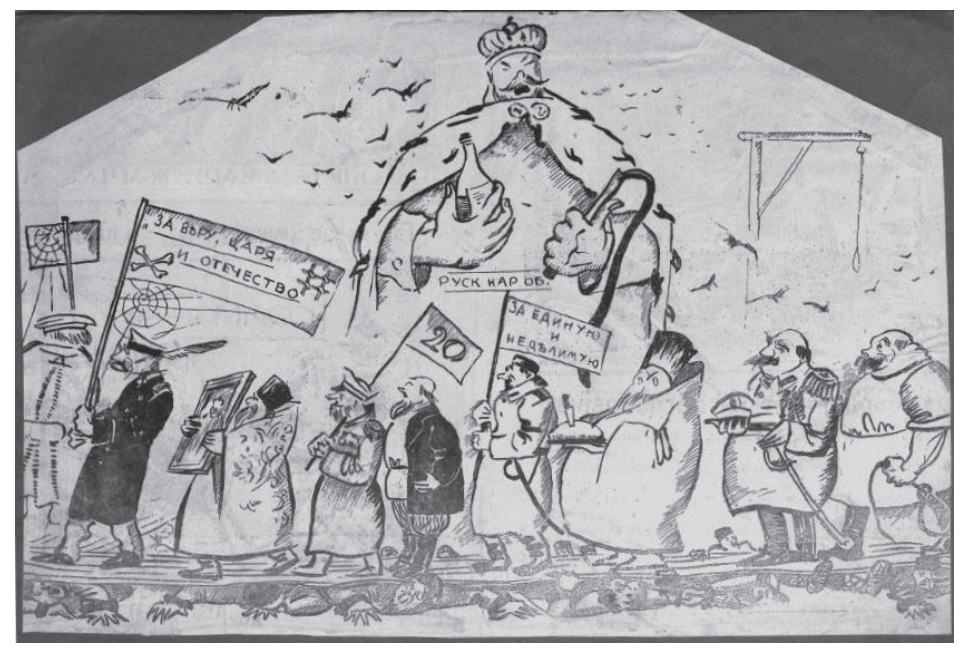

FIGURE 16: 'The monarch and procession', author unknown (Archive)

While criticizing Polish nationalists and monarchists is quite logical for the Hramada movement, it is surprising to learn that fellow Belarusian politicians and journalists also became the target of Malanka. Among others, Dr. Paŭliukievič, an active anti-communist, who published the newspaper Bielaruskaje Slova, became subject of the journal's focus. Authors today even consider that this contradictory personality was simultaneously working for both Polish and Soviet security forces (Krapivin 2007). This presumably former čarnasocieniec ${ }^{4}$ (Lis 1981, 47), was undoubtedly condemned by Hramada. He and other representatives of West Belarusian organisations e.g. Bielaruskaja Dolia and Bielaruski Dzien' are depicted on the 'Three epic heroes' cartoon. The irony of Horyd's-cartoon becomes apparent when he depicts 'the slaves of Piłsudski' as powerful Russian warriors (Lis 1981, 49). At the crossroads, they encounter a stone saying: 'Coming with pan you will become pan's slave'. On the background, Horyd draws a Belarusian village with lightning over it.

4 A representative from a far-right organisation in the Russian Empire. 


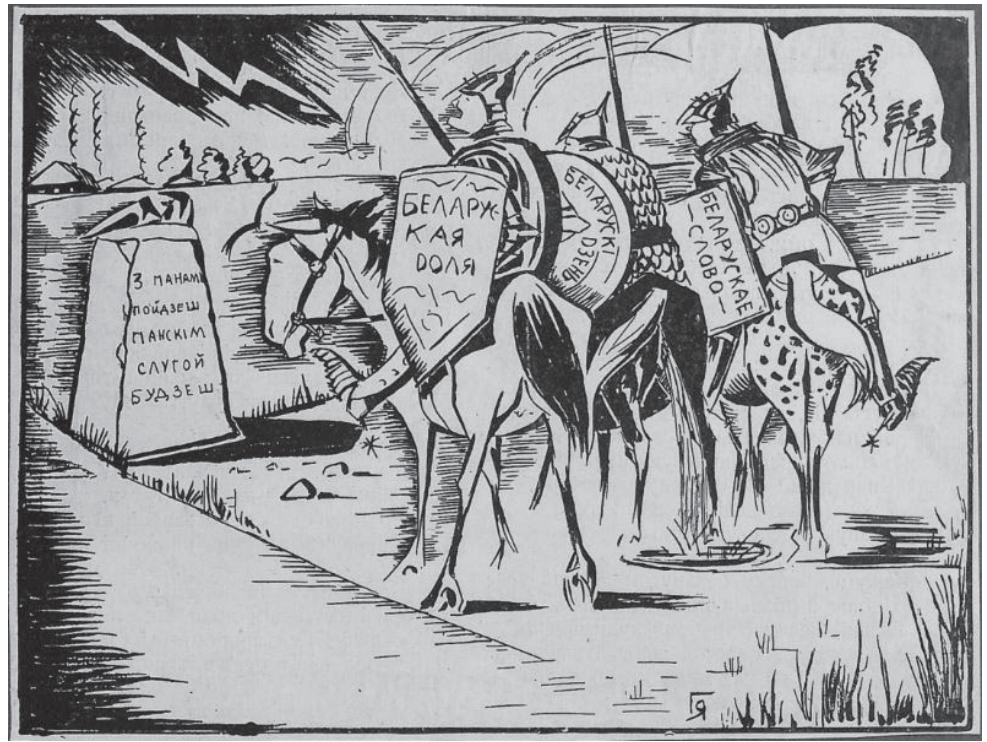

FIGURE 17: ‘Three epic heroes’, by Ja. Horyd (Archive)

Paŭliukievič is often mentioned directly too, in the jokes and cartoons.

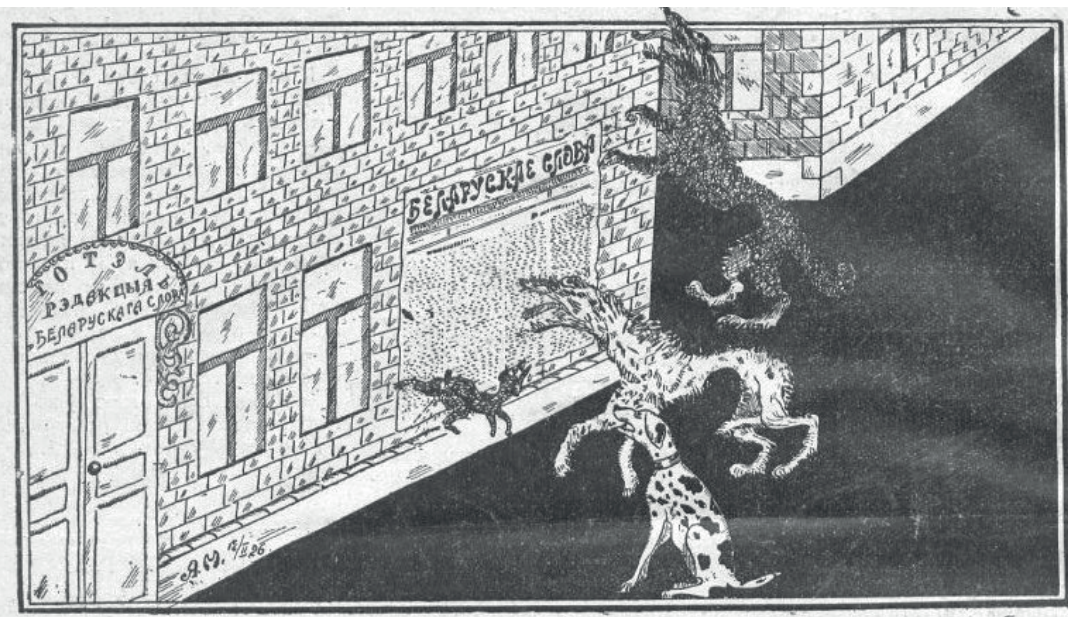

I я н ы 3 н а ю ц

Кажуць людзі, што толькі сабакі брэшуць, а тут у гэтай газэтцы «доктар» Павлюкевіч гэтак брэша, што нават ніякі сабака не патрапіць.

FIGURE 18: 'They also know', by Ja. Malanka (Malanka 1926 (8): 4)

People say that only dogs bark, but here, in this newspaper,

Dr. Paŭliukievič barks so that not a single dog will get in. 


\section{The Frame of Presents}

It is also significant to mention quite an iterant frame in Malanka repeated by its cartoonists - depicting presents given by the Polish state to different strata of its population. For instance, Figure 19 presents a title page from the December issue with Józef Piłsudski as the main actor bringing various presents; this shows what to expect from him in the New Year 1927. Pany get the king on the top on the Christmas tree. Workers get unemployment, hunger, taxes, etc. At the bottom, there is a bucket with Agrarian reform and asadnik, ${ }^{5}$ the presents for Belarusians. Piłsudski's assistant keeps bringing the horns of plenty for him. The addressee has several hints which point that the main figure is Piłsudski. In the same way as the repeated details of Soviet and pro-Soviet cartoons guided the viewer, e.g. Mussolini's chin, the monocle of Chamberlain, the characteristic profile of Franco, the moustache, low thick eyebrows, Marshal's trousers, and boots with spurs became markers of Piłsudski (Golubev 2010, 216, 231, 232).

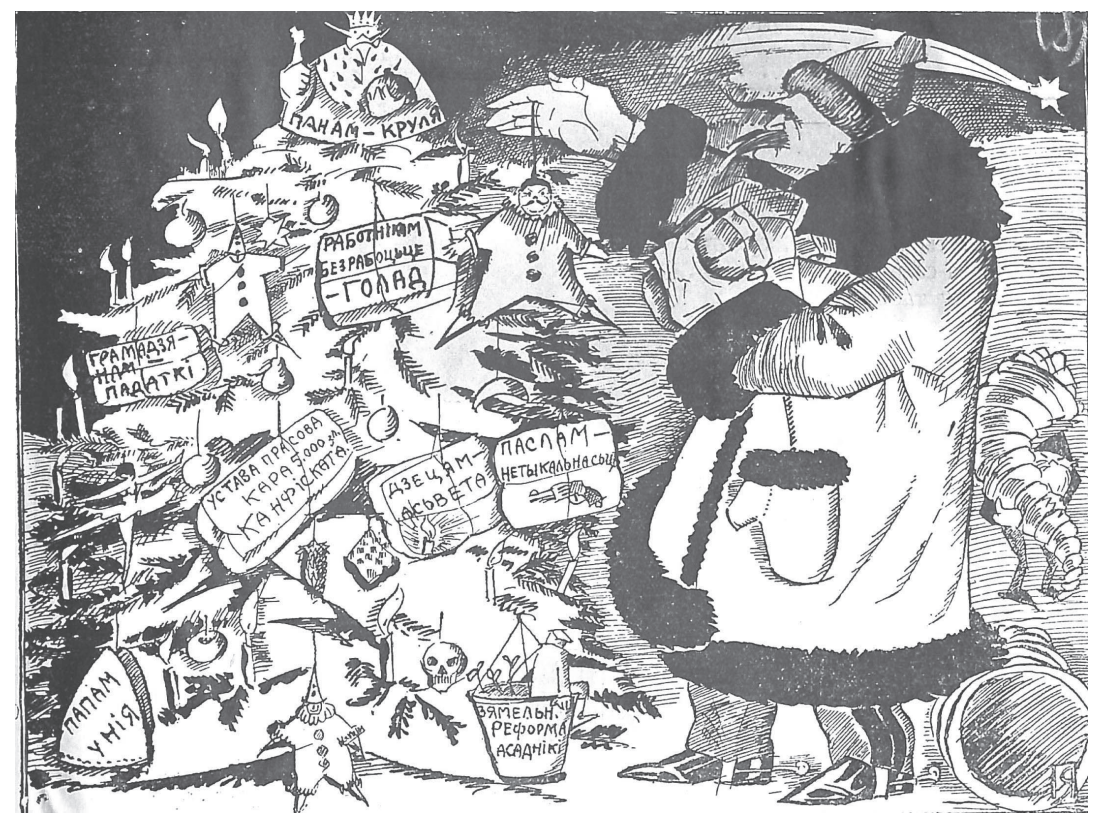

FIGURE 19: 'Piłsudski bringing presents', by Ja. Horyd (Archive)

Another cartoon in Malanka about New Year / Christmas presents was drawn by Janka Malanka. Here a less recognizable figure carries gifts in the form of language laws, taxes, declarations, asadniki, school matters, etc.

5 Polish military settler on the West Belarusian lands. 


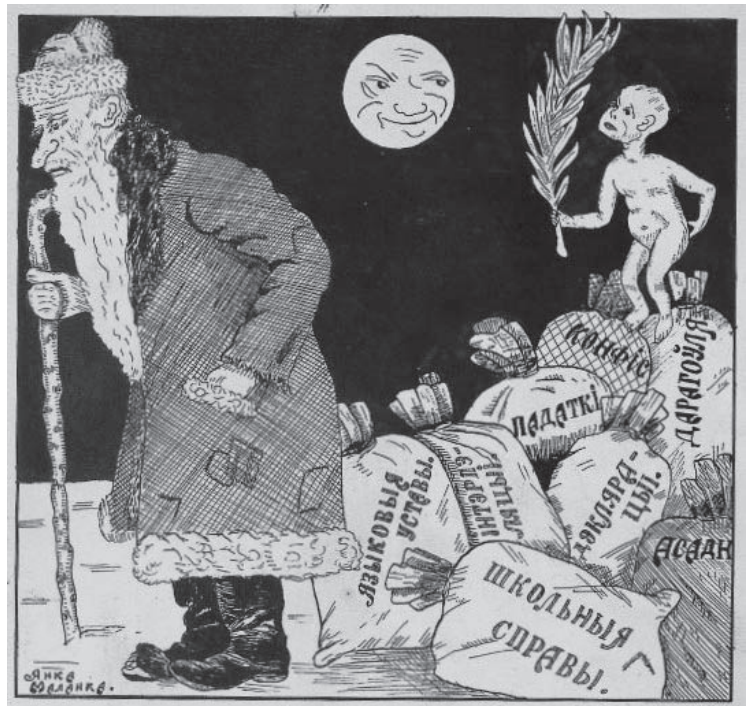

FIGURE 20: 'Presents in sacks', by Ja. Malanka (Archive)

Prepared not only as Christmas or New Year presents, the gifts also include Easter eggs, promise of taxation, the reduction of Belarusian teachers, arrests, confiscations, etc.

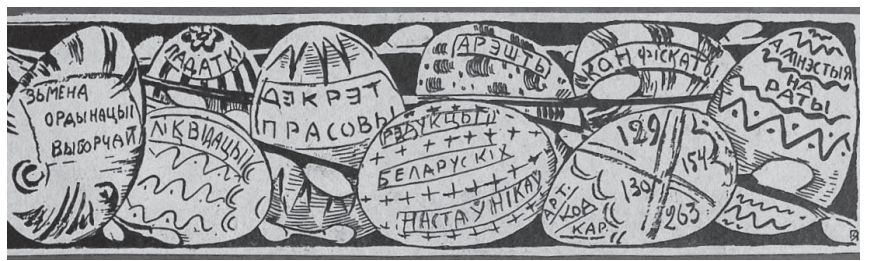

FIGURE 21: 'Easter eggs', author unknown (Archive)

\section{Capitalist Others}

Even though Poles, in their particular personifications of officials, landlords, public servants, etc., were the main protagonists of Malanka cartoons, the caricatures also kept in line with the Soviet tradition of cartoons depicting global capitalist as others. A prominent feature of many political caricatures is the repetition and recognition of several 'masks', including the imperialist with the cylinder, the monocle, and a bag with money, as a rule deprived of national signs, but sometimes with an obvious hint of English (Golubev 2010, 216) or American origin. Malanka employs these signs too. For instance, in the following cartoon, a Lithuanian and a Pole argue over Viĺnia, the notorious subject of disputing with different parties 
claiming their ownership. One of these claimers might be a Belarusian too, standing aside with the map of Belarus. The argument is already hot enough since the British fuels the conflict between two other parties and keeps a bouquet of figs in his hand. He becomes easily recognizable by the flag on his cylinder.

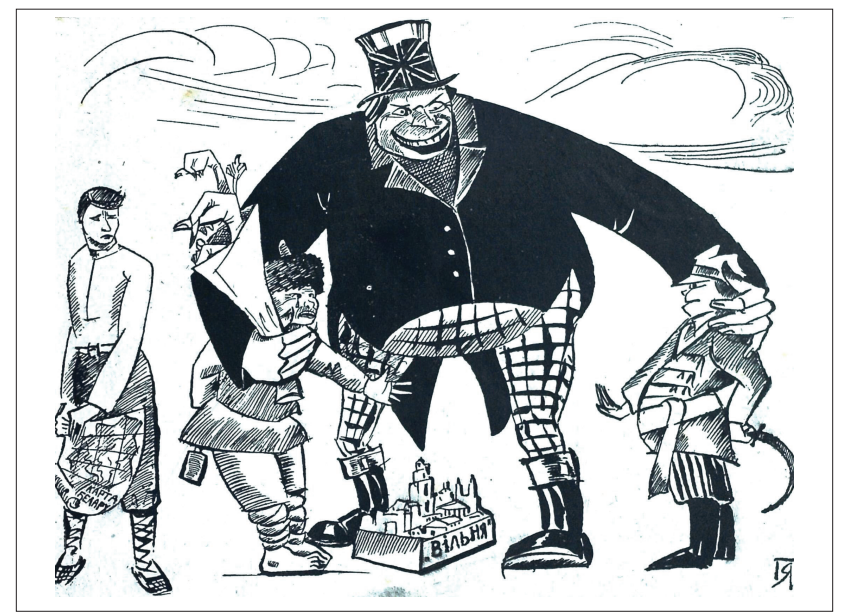

FIGURE 22: ‘Dispute over Viĺnia’, by Ja. Horyd (Archive)

So does the American. His capitalist essence manifests itself by the cylinder, while he is distinguished by the stars on his clothes. The American is feeding dying Polish currency with its dollars, but zloty's death is already nearby waiting at its window.

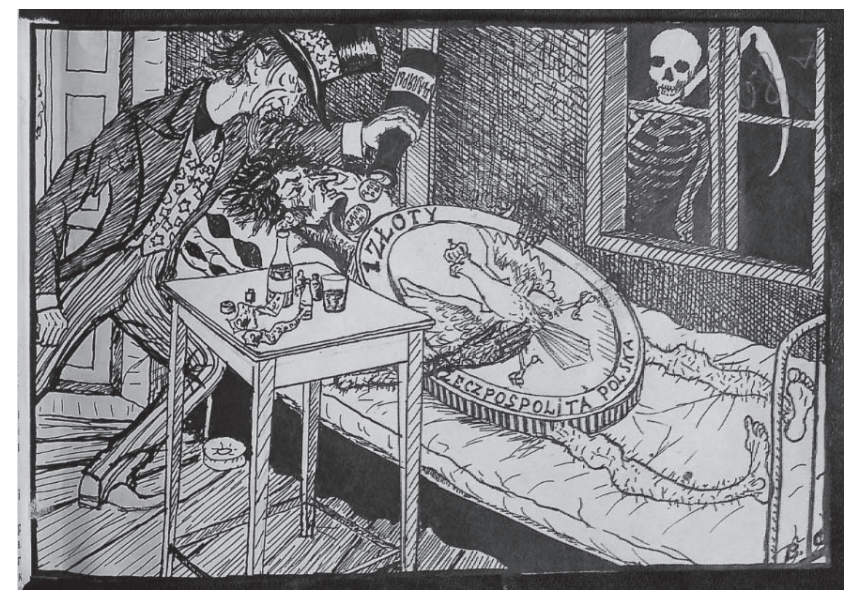

FIGURE 23: 'America feeding Polish zloty', by V.S. [most probably, Vasiĺ Sidarovič] (Archive)

Similarly, Malanka often laughs at the League of Nations, the international organisation established on the end of World War I with the primary aim to maintain 
peace and set international disputes. The League included 58 states at its peak, with neither of permanent and foundation members of the council, France, Japan, Italy, and Great Britain, being an ally of the Soviet Union. The USSR was not a member of the League until 1934. Thus, understood as hostile or useless, the League was often laughed at in Malanka.

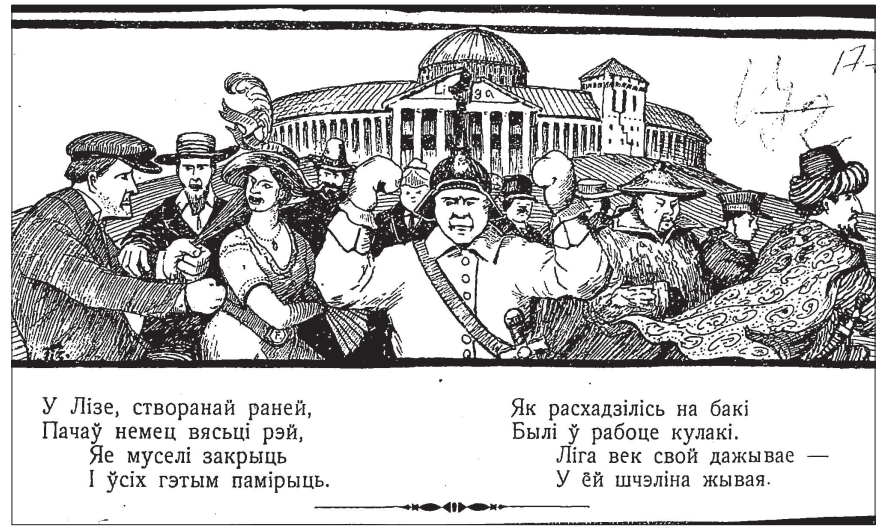

FIGURE 24: 'The League of Nations', author unknown (Archive)

In the League created earlier, / The German started to govern, / It was supposed to be closed. / And reconcile everyone with the help of that. / When they were stepping aside / their fists worked. / The League is being finished - / there is a life crack in it.

Unfortunately, the response of the target audience to Malanka's main topics remains unclear. The only feedback I managed to find is that published by Arsień Lis. He remembers the accounts of his uncle, who, at the time of Hramada, was even imprisoned as a secretary of a communist circle, having brothers in Soviet Russia. According to Lis, his uncle was also reading Malanka aloud to his village neighbours who enjoyed it (Lis 1981, 18-19).

\section{Józef Piłsudski's Coup d'État and the ban of Hramada}

At the end of 1926 and the beginning of 1927, the situation was becoming more and more difficult for Hramada. The obstacles the Belarusian movements faced before Piłsudski's 1926 May Coup d'État now seemed irrelevant. In 1927, the leaders of the Hramada, its Sejm deputies, and about 800 activists were arrested. The trial against Hramada became known as a trial of 56 (the number of the leaders of the prosecuted leaders of the movement), with its most significant defendant Branislaŭ Taraškievič and other important actors of Hramada sentenced to lengthy prison terms (Rudling 2015, 264). After these mass arrests, Hramada 
ceased to exist as a mass movement. The attempt of its continuation embodied by the creation of peasants and workers' club Zmahannie in 1928 was not successful (Šybieka 2003, 271).

The liquidation of Hramada caused a crisis of its press, which certainly reflected in all West Belarusian publications since Hramada's newspapers and journals constituted a significant part. Without their leaders, the Hramada papers were even more short-lived than before and mostly seized to exist. After the ban of one of the major publications, Naša Sprava, several new short-lived papers were established: Naš Holas, Naša Praca, Praca, Dumka Pracy, Prava Pracy, Da Pracy, Sila Pracy, Volia Pracy, Holas Pracy, Sciah Pracy, Dolia Pracy, Slova Pracy, Za Pracu (Per Rudling 2015, 260). The Belarusian newspapers were now censored on a regular basis.

For some months after the court case started, Malanka was still being published, responding to the arrest of Hramada leaders with a lot of satire:

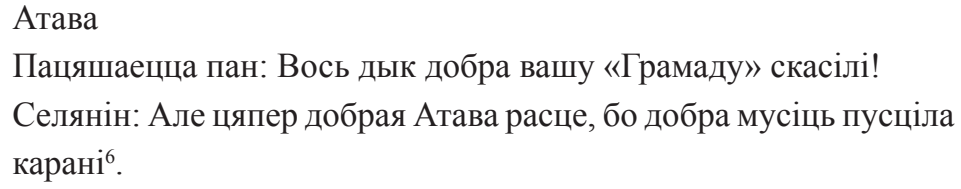

(In Kachanoŭski 1989, 31)

However, soon Malanka seized to exist. Its last issue was published with a lot of hardships in 1928. West Belarusian press quieted down. As the result of slight rapprochement in the relation with the USSR, it revived in 1933 with Bielaruskaja Hazeta, Asva, Litaraturnaja Staronka being allowed for publication. However, the rapprochement did not last long and these newspapers were closed in 1934 (Korienievskaia 2003).

\section{Conclusion}

Until now, the division of Belarus in 1921-39 remains 'uncomfortable past' (Paharely 2014a, 6) subject to radically different readings for the needs of different national myths. The analysis of the West Belarusian situation and its consequences is apparently possible not only through the archival documents, but also through its press, and, as in this article, through the trendy 1920s genre of political cartoons. The cartoons certainly may not be regarded as an objective description of the outside world, but as reflecting the inside imaginaries. The imaginaries, in turn, do not necessarily mean wrong or untrue images, but rather values and representations

6 Eddish. Pan laughs: 'Good that your Hramada was mowed!' The peasant: 'But now good eddish grows, as it must have been well-rooted'. 
of collective imagination. These imaginaries were pushed into the masses, addressing the main problems the readers supposedly had e.g. Polish officialdom, bureaucracy, Polonization, taxes, poverty, unemployment, etc. The long-existent stereotypes of oppressive pany now transformed into those of oppressive capitalist Poles, with the poor Belarusian peasant/worker suffering from this oppression. Poverty of the Belarusians caused by Poles became one of the major issues.

In addition to tackling these locally important issues, the publishers also targeted global opponents of their own values, in particular, capitalist countries, their unions, and allies. Moreover, in its cartoons, Malanka vividly embodied its criticism against the hostile parties, mainly national conservative and monarchist, sometimes concentrating on their particular actors. Often, the cartoonists depicted the actors' politics in the frame of presents; their distribution between the Belarusian minority and other groups of the population appeared to be unequal. The recurrent frame of gifts was complemented with other regular markers, e.g. capitalist cylinders, which, perhaps, helped express the message easier.

Despite the similarity of general tendencies, certain markers and aims, Malanka remained very different from the journals on the Soviet side of the border. Tied to its locality and concentrating on Western Belarusian targets, e.g. pany and Polish national democrats, Malanka seems to have had a much wider range of possible topics than its Soviet counterparts. In the latter, non-conformism and thematic differences from mainstream were already hardly possible. In comparison, the diversity and flexibility of the cartoons in Malanka, along with the extent to which it could criticize the officialdom, characterizes this journal as well as other publications of the West Belarusian press as the product of democratic liberties.

\section{References}

Archiŭ Nacyjanaĺnaha mastackaha museja Respubliki Bielaruś. Materyjaly dlia apublikavannia ŭ časopisie Malanka: partrety, zamalioŭki, šaržy, karykatury i inš. F. Aliachnoviča, Ja. M. Horyda, A. Vasilieǔskaha, Ja. Malanki i inš. Za 1926-1928 h. Papiera, piaro, tuš, vyrazki z hazet. Kaliekcyja dakumientaŭ addziela rukapisaŭ Bielaruskaha museja imia Ivana Luckieviča ŭ h. Viĺnia, 59-60.

Bekus, Nelly, 2010. Struggle over Identity: The Official and the Alternative 'Belarusianness', Budapest: Central European University Press.

Blanke, Richard, 1990. 'The German Minority in Inter-War Poland and German Foreign Policy - Some Reconsiderations', Journal of Contemporary History, 25, pp. 87-102. 
Bryhadzin, Piotr, Ladyseŭ, Uladzimir, Zialinski, Piotr and others (eds), 2002. Historyja Bielarusi. U $2 \check{c}$. Č. 2. XIX-XX stahoddzi, Minsk: RIVŠ BDU.

Buchowski, Krzysztof, 2010. 'Poles and Lithuanians: Respective Images in Caricatures from the First Half of the Twentieth Century', in Dagnosław Demski and Kamila Baraniecka-Olszewska (eds), Images of the Other in Ethnic Caricatures of Central and Eastern Europe, Warsaw: Institute of Archaeology and Ethnology, Polish Academy of Science, pp. 298-315.

Cohen, Michael, 2007. 'Cartooning Capitalism': Radical Cartooning and the Making of American Popular Radicalism in the Early Twentieth Century', in Marjolein t'Hart and Dennis Bos (eds), Humour and Social Protest. Cambridge: Press Syndicate of the University of Cambridge, pp. 35-58.

Chistov, Kirill, 2003. Russkaia narodnaia utopia (genezis i funktsii sotsial'no-utopicheskikh legend). Saint-Petersburg: 'Dmitrii Bulanin'.

Demski, Dagnosław and Baraniecka-Olszewska, Kamilla, 2010. 'Introduction. Encountering Images of the Other', in Dagnosław Demski and Kamila Baraniecka-Olszewska (eds), Images of the Other in Ethnic Caricatures of Central and Eastern Europe, Warsaw: Institute of Archaeology and Ethnology, Polish Academy of Science, pp. 11-25.

Demski, Dagnosław, 2013. 'Playing with Otherness: within and beyond the Stereotypes in Visual Representation', in Dagnosław Demski, Ildikó Sz. Kristóf and Kamila Baraniecka-Olszewska (eds), Competing Eyes: Visual Encounters with Alterity in Central and Eastern Europe, Budapest: L'Harmattan, pp. 68-99.

Dmitriev, Anatolii, 1998. Sotsiologia politicheskogo iumora: ocherki, Moscow: Rosspen.

Dmowski, Roman, 1904. Myśli Nowoczesnego Polaka, 2nd ed., Lwów: Nakładem Towarzystwa Wydawniczego.

Dubaviec, Siarhej, 1999. 'Naša Niva', in Paškoŭ H. P. and others. Encyklapiedyja historyi Bielarusi, t. 5 M-PUD, Minsk: 'Bielaruskaja encyklapiedyja' imia Pietrusia Broŭki, p. 316.

Golubev, Alexander, 2010. 'Images of the Eastern Europe in the Soviet Caricature of the 1920s and 1930s (in the Published Material of Krokodil)', in Dagnosław Demski and Kamila Baraniecka-Olszewska (eds), Images of the Other in Ethnic Caricatures of Central and Eastern Europe, Warsaw: Institute of Archaeology and Ethnology, Polish Academy of Science, pp. 212-233.

Gres', Siergei, 2014a. ‘Agrarnyie rieformy pol'skikh vlastiei na tierritorii Zapadnoi Bielarusi v miezhvoiennoe vriemia (partselliaciia i khutorizatsiia)', in Gu- 
manitarnyie nauchnyie issliedovaniia, 1, <http://human.snauka.ru/2014/01/5579> [accessed 20 June 2015].

—, 2014b. 'Agrarnyi vopros v programmakh politichieskikh partii v Zapadnoi Bielarusi', in Gumanitarnyie nauchnyie issliedovaniia, $10<\mathrm{http}: / /$ human.snauka. $\mathrm{ru} / 2014 / 10 / 7665>$ [accessed 20 June 2015].

Hirschman, Albert O., 1970. Exit, Voice, and Loyalty: Responses to Decline in Firms, Organisations, and States, Cambridge, MA: Harvard University Press.

Jackson, George D. Jr, 1966. Commintern and Peasant in East Europe, 19191930, New York, NY: Columbia University Press.

Kachanoŭski, Hienadź (comp.), 1989. Hej, smali, straliaj, Malanka!: satyra $i$ humar Zahodniaj Bielarusi (1920-1939 hh.), Minsk: 'CK KPB'.

Kasciuk, Michail, Ilaryjon, Ihnacienka and Vyšynski, Uladzimir and others, 1995. Narysy historyji Bielarusi: U 2 Č. 2. Minsk: Bielarus.

Kon, Felix, 1931a. 'Vviedieniie', in Boris Efimov, Karikatura na sluzhbie oborony SSSR, Moscow, Leningrad: OHIZ-IZOHIZ.

—, 1931b. 'Vviedieniie', in Boris Jefimov. Litso vraga. Risunki Borisa Iefimova, Moscow: Gosudarstviennoie Voiennoie Izdatel'stvo.

Konan, Uladzimir, 1999a. 'Naša Dolia', in Paškoŭ H.P. and others, Encyklapiedyja historyji Belarusi. t. 5 M-PUD, Minsk: 'Bielaruskaja encyklapiedyja' imia Pietrusia Broŭki, pp. 313-314.

—, 1999b. 'Naša Niva', in Paškoŭ H.P. and others, Encyklapiedyja historyji Bielarusi. t. 5 M-PUD, Minsk: 'Bielaruskaja encyklapiedyja' imia Pietrusia Broŭki, pp. 314-316.

Korienievskaia, Olga, 2003. 'Osobiennosti Zapadnobielorusskogo vozrozhdeniia (na primere pieriodicheskoi pechati', in Białoruskie Zeszyty Historyczne, $20<\mathrm{http}$ :// kamunikat.fontel.net/www/czasopisy/bzh/20/04.htm> [accessed 20 June 2015].

Kovkiel', Ivan and Iarmusik, Edmund, 2002. Istoria Bielarusi: $s$ drievnieishikh vriemion do nashiego vriemieni, Minsk: Aviersev.

Krapivin, Siergei, 2007. 'Tovarishch 'U' i dvoinoie ubiistvo 7 iiunia 1927 goda', in Ekspress novosti, 18 May <http:/www.expressnews.by/2403.html> [accessed 20 June 2015].

Laineste, Liisi, 2010. 'The Frighteningly Funny Foreigner: Caricatures of the Other in Estonian Interwar Public Discourse', Images of the Other in Ethnic Caricatures of Central and Eastern Europe, Warsaw: Institute of Archaeology and Ethnology, Polish Academy of Science, pp. 92-119. 
Ladysieŭ, Uladzimir and Bryhadzin, Piotr, 2003. Pamiž Uschodam i Zachadam: stanaŭliennie dziaržaunasci i terytaryjaĺnaj celasnasci Bielarusi (19171939 hh.), Minsk: BDU.

Lazari, Andrzej de and Riabov, Oleg, 2008. Polacy $i$ Rosjane we wzajemnej karykaturze, Warszawa: Polski Instytut Spraw Międzynarodowych.

Lis, Arsień, 1981. Piakučaj malanki slied: eciud da partreta mastaka Horyda, Minsk: Mastackaja litaratura.

—, 1994. Ciažkaja daroha svabody, Minsk: Mastackaja litaratura.

—, 1999. 'Naša Niva', in Paškoŭ, H.P. and others. Encyklapiedyja historyi Bielarusi. Tom 5 M-PUD, Minsk: 'Bielaruskaja encyklapiedyja' imia Pietrusia Broŭki, p. 316.

Lochmiel', Iosif, 1940. Ochierk istorii bor'by bielorusskogo naroda protiv pol'skikh panov, Moscow: Voenizdat.

Malanka, 1926-1928. Humarystyčny 2-ch tydniovy časopis, Viĺnia.

Martin, Terry, 2001. 'An Affirmative Action Empire', in Ronald G. Suny and Terry Martin (eds), A State of Nations, Oxford: Oxford University Press, pp. 67-90.

Maźko, Eduard, 2004. Savieckaja histaryjahrafija bielaruskaha nacyjanaĺnaha ruchu ŭ mižvajennaj Poĺščy (20-30-ia hh. XX st.), Histaryčny aĺmanach, 10, <http://kamunikat.fontel.net/www/czasopisy/almanach/10/09.htm> [accessed 20 August 2015].

Morgan, David, 2005. The Sacred Gaze. Religious Visual Culture in Theory and Practice, Berkeley: University of California Press.

Moskin, Dmitrij, 2000. Kratkaia entsiklopiedia karikatury. Iz istorii iumora $i$ satiry v grafike, Petrozavodsk: Petropriess.

Nalivajka, Liudmila and Šunejka, Jauhien, 2011a. 'Pramianistaja satyra', in Litaratura i mastactva, 33, p. 18.

—, 2011b. 'Dascipla, derzka, trapna', Litaratura i mastactva, 34, p. 18.

Nieviezhin, Vladimir, 2006. 'Obraz Pol'shi v sovietskoi karikaturie pierioda vtoroi mirovoi voiny (k postanovke probliemy)', in Andrzej de Lazari and Tatiana Rognińska (eds), Polacy i Rosjane. Przezwyciężanie uprzedzeń, Łódź: Ibidem, pp. 301-316.

Paharely, Aliaksandr, 2014a. 'Zachodniaja Bielaruś u mižvajenny čas', Arche, 7-8, pp. 6-8.

—, 2014b. "“Za novy typ bielarusa”: časopis "25 sakavika” (1936-1939) na fonie epochi', Arche, 7-8, pp. 120-194. 
Palujan, Uladzimir, 1967. Bielaruskaja sialianska-rabotnickaja hramada, Minsk: Navuka i tehnika.

Petrov, Petăr, 2010. 'Caricature as a Source in the Study of Mental Images: a Bulgarian Example', in Dagnosław Demski and Kamila Baraniecka-Olszewska (eds), Images of the Other in Ethnic Caricatures of Central and Eastern Europe, Warsaw: Institute of Archaeology and Ethnology, Polish Academy of Science, pp. 78-91.

Palujan, Vladimir and Palujan, Ivan, 1962. Rievoliutsionnoie $i$ natsional'no-osvoboditiel'noie dvizhenie v zapadnoi Bielorussii, Minsk: Gosudarstviennoie izdatiel'stvo BSSR.

Riabov, Oleg, 2006. 'Obraz vraga v sovietskoi politicheskoi karikature mezhvoiennogo pierioda. Sluchai Pol'shi', in Andrzej de Lazari and Tatiana Rogninska (eds), Polacy i Rosjane. Przezwyciężanie uprzedzeń, Łódź: Ibidem, pp. 275-285.

Rudling, Per Anders, 2015. The Rise and Fall of Belarusian Nationalism, 1906-1931, Pittsburgh, PA: University of Pittsburgh Press.

Savchenko, Andrew, 2009. Belarus - a Perpetual Borderland, Leiden: Brill Academic Publishers.

Šybieka, Zahar, 2003. Narys historyji Bielarusi (1795-2002), Minsk: Encyklapedyks.

Teune, Simon, 2008. 'Humour as Guerrilla Tactic: The West German Student Movement's Mockery of the Establishment', in Marjolein 't Hart and Dennis Bos (eds), Humour and Social Protest. Cambridge: Press Syndicate of the University of Cambridge, pp. 115-132.

Tokariev, V., 2006. 'Pol'skaia tiema za priedielami "Pravdy". Sovietskaia satirichieskaia grafika v stolichnykh i provintsial'nykh izdaniiakh', in Andrzej de Lazari and Tatiana Rognińska (eds), Polacy i Rosjane. Przezwyciężanie uprzedzeń, Łódź: Ibidem, pp. 281-330.

Tomaszewski, Jerzy, 2014. '1918-1939: Stračanyja dzesiacihoddzi?', Arche, 7-8, pp. 9-14.

Uhlíková, Lucie, 2005. 'Kulturní stereotypy v etnologii a v dalších společenských vědách', in Lubomír Tyllner and Zdeněk Uherek (eds), Kultura-společnost - tradice I. Soubor statí z etnologie, folkloristiky a sociokulturní antropologie, Praha: Etnologický ústav AV ČR, pp. 7-33.

Vaškievič, Andrej, 2006. 'Da pytannia ab uzajemaadnosinach Bielaruskaj Hryścijanskaj Demakratyji i Bielaruskaj Sialianska-Rabotnickaj Hramady', Histaryčny Aĺmanach, 12, pp. 47-51. 
Viačorka, Aliaksiej, 2014. 'Staronki žyćcia paliesskaha miastečka u mižvajenny čas. Na prykladze miastečka Haradnaja na Stolinščynie', Arche, 7-8, pp. 334-367.

Yurchak, Alexei, 2006. Everything Was Forever, Until It Was No More: The Last Soviet Generation, Princeton: Princeton University Press.

Zaprudnik, Jan, 1993. Belarus: At a Crossroads of History, Boulder, CO: Westview Press. 